\title{
Human Herpesvirus 8 Envelope Glycoprotein K8.1A Interaction with the Target Cells Involves Heparan Sulfate
}

\author{
FU-ZHANG WANG, SHAW M. AKULA, NARANATT P. PRAMOD, LING ZENG, AND BALA CHANDRAN* \\ Department of Microbiology, Molecular Genetics, and Immunology, The University of Kansas \\ Medical Center, Kansas City, Kansas 66160
}

Received 26 January 2001/Accepted 10 May 2001

\begin{abstract}
Human herpesvirus-8 (HHV-8) or Kaposi's sarcoma-associated herpesvirus K8.1 gene encodes for two immunogenic glycoproteins, gpK8.1A and gpK8.1B, originating from spliced messages. The 228-amino-acid (aa) gpK8.1A is the predominant form associated with the virion envelope, consisting of a 167-aa region identical to gpK8.1B and a 61-aa unique region (L. Zhu, V. Puri, and B. Chandran, Virology 262:237-249, 1999). HHV-8 has a broad in vivo and in vitro cellular tropism, and our studies showed that this may be in part due to HHV-8's interaction with the ubiquitous host cell surface molecule, heparan sulfate (HS). Since HHV-8 K8.1 gene is positionally colinear to the Epstein-Barr virus (EBV) gene encoding the gp350/gp220 protein involved in EBV binding to the target cells, gpK8.1A's ability to interact with the target cells was examined. The gpK8.1A without the transmembrane and carboxyl domains ( $\Delta \mathrm{TMgpK8.1A})$ was expressed in a baculovirus system and purified. Radiolabeled purified $\Delta$ TMgpK8.1A protein bound to the target cells, which was blocked by unlabeled $\Delta$ TMgpK8.1A. Unlabeled $\Delta$ TMgpK8.1A blocked the binding of $\left[{ }^{3} \mathrm{H}\right]$ thymidine-labeled purified HHV-8 to the target cells. Binding of radiolabeled $\Delta$ TMgpK8.1A to the target cells was inhibited in a dose-dependent manner by soluble heparin, a glycosaminoglycan (GAG) closely related to HS, but not by other GAGs such as chondroitin sulfate $A$ and $\mathrm{C}, N$-acetyl heparin and de- $N$-sulfated heparin. Cell surface absorbed $\Delta$ TMgpK8.1A was displaced by soluble heparin. Radiolabeled $\Delta$ TMgpK8.1A also bound to HS expressing Chinese hamster ovary (CHO-K1) cells, and binding to mutant CHO cell lines deficient in HS was significantly reduced. The $\Delta$ TMgpK8.1A specifically bound to heparin-agarose beads, which was inhibited by HS and heparin, but not by other GAGs. Virion envelope-associated gpK8.1A was specifically precipitated by heparinagarose beads. These findings suggest that gpK8.1A interaction with target cells involves cell surface HS-like moieties, and HHV-8 interaction with HS could be in part mediated by virion envelope-associated gpK8.1A.
\end{abstract}

Human herpesvirus 8 (HHV-8) or Kaposi's sarcoma-associated herpesvirus (KSHV) DNA has been detected in the Kaposi's sarcoma (KS) tissues from patients with AIDS-KS, classic KS, Africa-endemic KS, and transplantation-associated KS $(12,44)$. HHV-8 has a broad in vivo and in vitro cellular tropism. HHV-8 DNA and transcripts have been identified in vivo in human B cells (15), macrophages (4), endothelial cells $(5,52)$, and epithelial cells (16). In the KS tissues, HHV-8 DNA is present in a latent form in the vascular endothelial and spindle cells $(5,15,17,44,52)$. In addition, a low percentage of HHV-8 lytic cycle has been detected in the infiltrating inflammatory monocytes (4). HHV-8 DNA has been also detected in primary effusion lymphomas or body-cavity-based lymphomas (BCBL) $(9,17)$. BCBL cell lines such as BCBL-1 and BC-3 carry HHV-8 in a latent form, and a lytic cycle can be induced by 12 - $O$-tetradecanoylphorbol-13-acetate (TPA) $(3,17,27,40$, $44,50)$.

The in vitro infectious process of HHV-8 differ from many members of alpha-, beta-, and gammaherpesvirus families. HHV-8 has been shown to infect a variety of human and animal cells, such as human B cells, epithelial cells (293), human endothelial cells, human foreskin fibroblast (HFF)

\footnotetext{
* Corresponding author. Mailing address: Department of Microbiology, Molecular Genetics, and Immunology, The University of Kansas Medical Center, 3901 Rainbow Blvd., Kansas City, KS 66160-7420. Phone: (913) 588-7043. Fax: (913) 588-7295. E-mail: bchandra@kumc .edu.
}

cells, human carcinoma cells (bladder, prostate, lung, and squamous), owl monkey kidney cells, and baby hamster kidney (BHK-21) cells $(20,34,39,58)$. If in vitro permissiveness of a cell type is judged by a productive lytic replication of HHV-8 after entry into cells, there is as yet no suitable cell culture system to support a lytic replication of input HHV-8. Only a latent HHV-8 infection is observed in the infected cells $(20,34$, $39,58)$. However, if in vitro permissiveness is judged by the establishment of HHV-8 latency and the ability to support HHV-8 lytic replication after activation by agents, cells such as HFF, human carcinoma cells and endothelial cells are permissive, as evidenced by the retention of viral genome in a latent form, by the expression of HHV-8 latency-associated open reading frame (ORF) 73 protein and by the ability to support lytic replication upon activation by agents such as TPA or by human cytomegalovirus (HCMV) infection $(20,34,39,58)$.

Since the analysis of in vitro HHV-8 interaction with host cells and quantitation of infection has been hampered by the absence of the lytic replication cycle and a reliable plaque assay, to monitor the HHV-8 binding and entry process BCBL-1 cells carrying a recombinant HHV-8 expressing the green fluorescent protein (GFP-HHV-8) were established (58). In a recent study, using the GFP-HHV-8 in the supernatant of TPA induced BCBL-GFP cells as the inoculum for infection and the $\left[{ }^{3} \mathrm{H}\right]$ thymidine-labeled purified $\mathrm{HHV}-8$, we demonstrated that the broad cellular tropism of HHV-8 may be in part due to its interaction with the ubiquitous host cell surface HS molecule (2). This conclusion was based on the 
following findings: (i) HHV-8 infection of HFF cells was inhibited in a dose-dependent manner by soluble heparin, a glycosaminoglycan closely related to HS; (ii) enzymatic removal of HFF cell surface HS with heparinase I and III reduced HHV-8 infection; (iii) soluble heparin inhibited the binding of radiolabeled HHV-8 to human B-cell lines, embryonic kidney epithelial (293) cells, and HFF cells, suggesting interference at the virus attachment stage; (iv) cell surfaceadsorbed HHV-8 was displaced by soluble heparin; and (v) radiolabeled HHV-8 also bound to wild-type HS expressing Chinese hamster ovary (CHO-K1) cells. In contrast, binding of virus to mutant $\mathrm{CHO}$ cells deficient in $\mathrm{HS}$ was significantly reduced. These data suggested that the gamma-2-HHV-8 is adsorbed to cells by binding to cell surface HS-like moieties. In this respect, gamma-2-HHV-8 resembles some members of the alpha (herpes simplex virus type 1 [HSV-1], HSV-2, pseudorabies virus [PRV], bovine herpesvirus 1 [BHV-1])-, beta (HCMV, HHV-7)-, and gamma-2 (BHV-4)-herpesviruses, where the initial virus-cell interaction also involves the binding to the cell surface HS $(21,24,30,31,33,35,37,46,47,49,51$, 57).

The identity of HHV-8 envelope glycoprotein(s) involved in the interaction with HS is not known. HHV-8 encodes for more than 80 ORFs, and ORFs 4 to 75 are designated based on the similarity to herpesvirus saimiri (HVS) ORFs (1). HHV-8 unique ORFs are designated with the prefix K $(36,43)$. HHV-8 has counterparts to other herpesvirus glycoproteins such as $\mathrm{gB}$ (ORF 8), gH (ORF 22), gM (ORF 39), and gL (ORF47) (36, 43). In addition, $\mathrm{K} 1$ and $\mathrm{K} 8.1$ genes encode for glycoproteins unique for HHV-8 $(10,36,43)$. We have previously reported the identification of cDNAs originating from the HHV-8 K8.1 gene encoding two ORFs from spliced messages (10). One cDNA encoded for a 228-amino-acid (aa) protein designated gpK8.1.A and contains a signal sequence, transmembrane domain, and four $\mathrm{N}$-glycosylation sites. The splicing event has generated the transmembrane domain in the gpK8.1A ORF not seen in the genomic K8.1 ORF. Another cDNA encoded for an ORF of 167 aa, designated gpK8.1.B. This protein has three $\mathrm{N}$-glycosylation sites and shares similar amino and carboxy termini with ORF K8.1.A but with an in-frame deletion (10). Our studies with human sera demonstrated the immunogenic nature of gpK8.1A and gpK8.1B $(10,61)$. Using monoclonal antibodies (MAbs), we have also shown that gpK8.1A and gpK8.1B contain $\mathrm{N}$ - and O-linked sugars and that gpK8.1A is the predominant form detected within the infected cells and the virion envelopes (60).

HHV -8 K8.1 gene is positionally colinear to the glycoprotein genes in the members of gammaherpesvirus group such as the Epstein-Barr virus (EBV) gene encoding the major envelope glycoproteins gp350 and gp220 (22), gp150 of murine gammaherpesvirus 68 (MHV-68) (53), HVS ORF 51 gene (1), and the BORFD1 gene of BHV-4 (36, 43). EBV gp350/gp220 glycoprotein has been studied extensively and shown to be involved in the binding of the virus to the target cells (22). HHV-8 gpK8.1A shows several similarities to the EBV glycoproteins. Like EBV gp350/gp220, HHV-8 gpK8.1A elicits a strong human humoral immune response (61) and is a virion envelopeand infected cell membrane-associated glycoprotein containing both $\mathrm{N}$ - and O-linked sugars. Because of these similarities to EBV gp350/gp220, we examined the ability of HHV-8
gpK8.1A to interact with the target cells. We expressed gpK8.1A without the transmembrane and carboxyl domains ( $\Delta$ TMgpK8.1A) in the baculovirus system and purified the protein. Using radiolabeled purified $\Delta \mathrm{TMgpK} 8.1 \mathrm{~A}$, we show that gpK8.1A interaction with target cells involves cell surface HS-like moieties. These results suggest that HHV-8 interaction with $\mathrm{HS}$ could be in part mediated by virion envelope gpK8.1A.

\section{MATERIALS AND METHODS}

Cells. HFF cells, 293 cells, CHO-K1 cells (ATCC CCL-61), HS-deficient CHO derivative pgsD-677 cells (ATCC CRL-2244), HS-and chondroitin sulfate-deficient $\mathrm{CHO}$ derivative pgsA-745 cells (ATCC CRL-2242) (18, 32), BCBL-1 cells (HHV $-8^{+}$human B cells) $(40,50)$, and BJAB cells $\left(\mathrm{HHV}-8^{-}\right.$human B cells) were used in this study. HFF and 293 monolayer cells were grown in Dulbecco modified Eagle medium (DMEM; Gibco-BRL, Grand Island, N.Y.) supplemented with $2 \mathrm{mM}$ glutamine, $10 \%$ fetal bovine serum (FBS), and antibiotics. Suspension cultures of 293 cells were grown in 293-SF medium (Gibco-BRL). Adult human dermal microvascular endothelial cells (HMVEC-d Ad; CC-2543; Clonetics, San Diego, Calif.) were grown in endothelial growth medium (EGM; CC-3202; Clonetics). Monolayers of CHO-K1, pgsD-677, and pgsA-745 cells were grown in Ham's F-12K medium (Gibco-BRL) supplemented with $10 \%$ FBS and antibiotics. Suspension cultures of BCBL-1 and BJAB cells were grown in RPMI 1640 medium with glutaMAX I (Gibco-BRL) supplemented with 10\% FBS and antibiotics. Spodoptera frugiperda ovarian cells (Sf9) were grown in TNM-FH insect medium (PharMingen, San Diego, Calif.).

Antibodies. The production and characterization of MAbs against gpK8.1A and ORF 59 have been described previously (11, 60). High-titer-antibody-containing ascitic fluids were made by injecting hybridoma cells intraperitoneally into pristane-primed BALB/c mice. Immunoglobulin $\mathrm{G}(\mathrm{IgG})$ antibodies from the ascitic fluid and normal mouse sera were purified on protein A-Sepharose columns (Amersham Pharmacia Biotech AB, Uppsala, Sweden). Protein concentrations were adjusted to $1 \mathrm{mg} / \mathrm{ml}$ with phosphate-buffered saline (PBS; $\mathrm{pH}$ 7.4), and aliquots were stored at $-20^{\circ} \mathrm{C}$. Rabbit polyclonal antibodies raised against the baculovirus-expressed purified glutathione $S$-transferase-HHV-8 latency-associated ORF 73 protein $(34,58,61)$ were used as a control.

Construction, expression, and purification of recombinant HHV-8 $\triangle \mathrm{TMgpK8.1A}$. The 576-bp $\Delta$ TMgpK8.1A gene region encoding aa 1 to 192 lacking the transmembrane and the carboxyl domains was amplified from the full-length $\mathrm{HHV}-8$ gpK8.1A cDNA (10) using the primers $\triangle$ TMgpK8.1A forward (5'-TTC CGC GTG AGC TCA TGA GTT CCA CAC AGA-3' with a SacI site) and $\Delta$ TMgpK8.1A reverse (5'-GAT GGG TCG GTA CCT CTG CAT TGT AGT-3' with a KpnI site) (Advantage cDNA PCR Kit; Clontech, Palo Alto, Calif.). The $\Delta$ TMgpK8.1A PCR product was cloned into the pAcHLT-A baculovirus transfer vector (PharMingen) and verified by sequencing. To generate the recombinant baculovirus, $\Delta$ TMgpK8.1A-pAcHLT-A plasmid was cotransfected with BaculoGold DNA (PharMingen) into Sf9 insect cells. Recombinant viruses were passaged three times before use.

His-tagged $\Delta \mathrm{TMgpK} 8.1 \mathrm{~A}$ was expressed in Sf9 cells and purified using nickel columns (PharMingen) according to the manufacturer's recommendations. Briefly, Sf9 cells were infected with $\Delta$ TMgpK8.1A-baculovirus and, at 2 days postinfection, the cells were labeled with $\left[{ }^{35} \mathrm{~S}\right]$ methionine for $20 \mathrm{~h}$. Cell pellets were lysed with lysis buffer $(10 \mathrm{mM}$ Tris, $\mathrm{pH} 7.5 ; 130 \mathrm{mM} \mathrm{NaCl} ; 1 \%$ Triton $\mathrm{X}-100 ; 10 \mathrm{mM} \mathrm{NaF} ; 10 \mathrm{mM}$ sodium orthophosphate; $10 \mathrm{mM}$ sodium pyrophosphate), and centrifuged at $40,000 \times g$ for $45 \mathrm{~min}$ at $4^{\circ} \mathrm{C}$, and the clear supernatant was passed through an Ni-nitrilotriacetic acid-agarose column. The column was washed extensively with lysis buffer, followed by lysis buffer with 20 and $30 \mathrm{mM}$ imidazole. Washes were monitored by measuring the optical density at $280 \mathrm{~nm}$. When the $A_{280}$ reached a value of $<0.01$, column-bound protein was eluted with 0.1 to $0.5 \mathrm{M}$ imidazole and collected in $0.5-\mathrm{ml}$ fractions. The purity of the eluted protein was analyzed by silver staining of sodium dodecyl sulfate (SDS) $-12 \%$ polyacrylamide gel electrophoresis (PAGE) gels, by Western blots with antigpK8.1A MAb, and by autoradiography (60). Fractions containing the purified protein were pooled, dialyzed against PBS, concentrated, and reanalyzed as described above. His-tagged HHV-8 latency-associated ORF 73 protein (61) used as control was purified from Sf9 cells infected with ORF 73-pAcHLT-A baculovirus as described above.

Western blot assays. Samples were boiled in sample buffer with 2-mercaptoethanol (2-ME), subjected to SDS-PAGE, and electrophoretically transferred onto nitrocellulose membranes. Standard prestained molecular weight markers 
(Gibco-BRL) were included in parallel lanes. The membranes were soaked in blocking solution (10 mM Tris- $\mathrm{HCl}, \mathrm{pH} 7.2 ; 150 \mathrm{mM} \mathrm{NaCl} ; 5 \%$ skim milk or $5 \%$ bovine serum albumin [BSA]; $0.02 \% \mathrm{NaN}_{3}$ ) at $4^{\circ} \mathrm{C}$ overnight and then reacted with antibodies for $3 \mathrm{~h}$ at room temperature. The membranes were washed five times with washing buffer (10 mM Tris- $\mathrm{HCl}, \mathrm{pH} 7.2 ; 150 \mathrm{mM} \mathrm{NaCl} ; 0.3 \%$ Tween 20) and incubated for $1 \mathrm{~h}$ with alkaline phosphatase (AP)-conjugated secondary antibodies (KPL, Gaithersburg, Md.). Bound enzyme-labeled antibodies were detected by evaluating the color reaction of AP with nitroblue tetrazolium and BCIP (5-bromo-4-chloro-3-indolyphosphate) substrates (Sigma). The reactions were stopped by washing the membranes in distilled water.

Surface immunofluorescence assay (SIFA). To detect the binding of gpK8.1A and $\Delta$ TMgpK8.1 to the cell surface, BJAB and 293 suspension cells or HFF and 293 cell monolayers in chamber slides were used $(2,60)$. A suspension of cells $\left(10^{7}\right)$ was washed once with RPMI 1640 , resuspended in $10 \mathrm{ml}$ of ice-cold $0.1 \%$ paraformaldehyde in PBS ( $\mathrm{pH} 7.4$ ), and centrifuged at $125 \times \mathrm{g}$ for $10 \mathrm{~min}$. The cells were washed twice, the concentration was adjusted to $10^{6}$ cells per ml, the cells were centrifuged for $10 \mathrm{~min}$ at $125 \times g$ and the supernatants were discarded. Dilutions of purified gpK8.1A $(1 \mu \mathrm{g} / \mathrm{ml})$ and $\Delta$ TMgpK8.1A $(1 \mu \mathrm{g} / \mathrm{ml})$ in $200 \mu \mathrm{l}$ of RPMI 1640 with $10 \%$ FBS were added to the cell pellets, mixed, and incubated for $30 \mathrm{~min}$ at $37^{\circ} \mathrm{C}$. These cells were washed five times with RPMI 1640 with $0.01 \% \mathrm{NaN}_{3}$ and then incubated with prestandardized dilutions of gpK8.1A $\mathrm{MAb}$ or control antibodies for $30 \mathrm{~min}$ at $37^{\circ} \mathrm{C}$. Cells were washed five times with RPMI 1640 with $0.01 \% \mathrm{NaN}_{3}$ and incubated for 30 min at $37^{\circ} \mathrm{C}$ with prestandardized fluorescein isothiocyanate (FITC)-conjugated goat anti-mouse or antirabbit IgG antibodies. Cells were washed and mounted on glass slides, and cell-bound gpK8.1A was examined under a fluorescence microscope. For binding with monolayers, cells were treated with $0.1 \%$ paraformaldehyde, washed five times with RPMI 1640, incubated with dilutions of purified proteins, and processed as described above.

Radiolabeled $\Delta$ TMgpK8.1A binding assays. A protein binding assay was performed according to the method described previously (6), with minor modifications. Briefly, confluent monolayers of HFF, 293, HMVEC-d, CHO-K1, and CHO mutant derivative cells in 96 - or 24-well plates were washed and blocked for $30 \mathrm{~min}$ at $4^{\circ} \mathrm{C}$ with PBS containing $1 \%$ FBS, $5 \mathrm{mM}$ albumin, and $0.1 \mathrm{mM}$ $\mathrm{CaCl}_{2}$. Cells were incubated with different concentrations of purified $\Delta$ TMgpK8.1A $(7,666 \mathrm{cpm} / \mu \mathrm{g}$ of protein) or purified ORF 73 protein $(14,672$ cpm) in DMEM with $10 \%$ FBS and $0.01 \% \mathrm{NaN}_{3}$ for $90 \mathrm{~min}$ at $4^{\circ} \mathrm{C}$. After incubation, cells were washed five times with DMEM and lysed with $1 \%$ SDS and $1 \%$ Triton $\mathrm{X}-100$ in distilled water, and the cell-bound $\Delta \mathrm{TMgpK} 8.1 \mathrm{~A}$ radioactivity was counted. All experiments were done in triplicate and were repeated three times.

For homologous competition assays, confluent HFF cells were preincubated with different concentrations of nonlabeled $\Delta \mathrm{TMgpK} 8.1 \mathrm{~A}$ for $15 \mathrm{~min}$ at $4^{\circ} \mathrm{C}$ and then incubated with 3.5 and $15 \mu \mathrm{g}$ of labeled $\Delta \mathrm{TMgpK} 8.1 \mathrm{~A}$ for the 96 - and 24-well plates, respectively, for $90 \mathrm{~min}$ at $4^{\circ} \mathrm{C}$. Cells were washed five times, lysed with $1 \%$ SDS and $1 \%$ Triton X-100 in distilled water, and counted. Each reaction was done in triplicate and repeated three times.

To test the ability of heparin to inhibit $\Delta \mathrm{TMgpK} 8.1 \mathrm{~A}$ binding, a constant quantity of purified labeled $\Delta \mathrm{TMgpK} 8.1 \mathrm{~A}$ (3.5 and $15 \mu \mathrm{g}$ for the 96 - and 24-well plates, respectively) was mixed with medium alone or medium with different concentrations of heparin and then incubated at $4^{\circ} \mathrm{C}$ for $90 \mathrm{~min}$. These mixtures were then added to the target cells, followed by incubation at $4^{\circ} \mathrm{C}$ for $90 \mathrm{~min}$, and then washed five times with DMEM and lysed with $1 \%$ SDS and $1 \%$ Triton $\mathrm{X}-100$ in distilled water. The cell-bound $\Delta \mathrm{TMgpK} 8.1 \mathrm{~A}$ counts per minute (cpm) in the presence or absence of heparin and the percentage of inhibition of binding were calculated. All reactions were done in triplicate and were repeated three times.

The specificity of HS binding was determined by incubating HFF cell monolayers with labeled $\Delta \mathrm{TMgpK} 8.1 \mathrm{~A}$ (3.5 and $15 \mu \mathrm{g}$ for the 96- and 24-well plates, respectively). At different time points, the cells were incubated with medium alone (controls) or with medium containing heparin $(10 \mu \mathrm{g} / \mathrm{ml})$. Cells were further incubated for $90 \mathrm{~min}$ at $4^{\circ} \mathrm{C}$, washed five times, lysed with $1 \%$ SDS and $1 \%$ Triton X-100 in distilled water, and counted. The cell-associated $\Delta \mathrm{TMgpK} 8.1 \mathrm{~A} \mathrm{cpm}$ in the presence or absence of heparin and the percentage of inhibition of $\Delta \mathrm{TMgpK} 8.1 \mathrm{~A}$ binding were calculated. All reactions were done in triplicate and were repeated three times.

Blocking HHV-8 binding by purified $\Delta$ TMgpK8.1A. Radiolabeled HHV-8 binding assay was performed using HFF cells as per methods described previously (2). Briefly, HFF cells were incubated with increasing concentrations of purified unlabeled $\Delta \mathrm{TMgpK} 8.1 \mathrm{~A}$ for $90 \mathrm{~min}$ at $4^{\circ} \mathrm{C}$, followed by the addition of a fixed quantity of $\left[{ }^{3} \mathrm{H}\right]$ thymidine-labeled purified HHV-8 (2,684 cpm) (2). For a control, a fixed quantity of $\left[{ }^{3} \mathrm{H}\right]$ thymidine-labeled purified HHV-8 $(2,684 \mathrm{cpm})$ was mixed with $10 \mu \mathrm{g}$ of heparin per $\mathrm{ml}$ for $90 \mathrm{~min}$ at $4^{\circ} \mathrm{C}$ and then added to HFF cells. After incubation for $90 \mathrm{~min}$ at $4^{\circ} \mathrm{C}$ with the virus, cells were washed five times and lysed with $1 \%$ SDS and $1 \%$ Triton $\mathrm{X}-100$, and the radioactivity was precipitated with trichloroacetic acid (TCA) and counted. The cell-associated virus cpm in the absence or presence of unlabeled $\Delta \mathrm{TMgpK} 8.1 \mathrm{~A}$ or heparin and the percentage of inhibition of virus binding were calculated. All reactions were done in triplicate and repeated three times.

$\Delta$ TMgpK8.1A binding with heparin-agarose. Purified $\Delta$ TMgpK8.1A $(3.5 \mu \mathrm{g})$ was preincubated with $350 \mu \mathrm{g}$ of various glycosaminoglycans (GAGs) such as heparin, HS, chondroitin sulfate A (CS-A), chondroitin sulfate B (CS-B), chondroitin sulfate $\mathrm{C}(\mathrm{CS}-\mathrm{C}), N$-acetyl heparin, and de- $N$-sulfated heparin (Sigma). After being mixed for $1 \mathrm{~h}$ at $4^{\circ} \mathrm{C}, 100 \mu \mathrm{l}$ of a $50 \%$ slurry of heparin-agarose beads (Sigma) equilibrated in radioimmunoprecipitation assay (RIPA) lysis buffer (0.05 M Tris hydrochloride, $\mathrm{pH} 7.5 ; 0.15 \mathrm{M} \mathrm{NaCl} ; 1 \%$ sodium deoxycholate; $1 \%$ Triton X-100, $100 \mathrm{U}$ of aprotinin per $\mathrm{ml} ; 0.1 \mathrm{mM}$ phenylmethylsulfonyl fluoride) (60) was added and further mixed for $2 \mathrm{~h}$ at $4^{\circ} \mathrm{C}$. The heparin-agarose beads were washed five times in RIPA buffer. The bound material was eluted by boiling the beads in sample buffer with 2-ME, resolved by SDS-12\%PAGE, Western blotted, and analyzed with anti-gpK8.1A MAb.

The specificity of $\Delta \mathrm{TMgpK} 8.1 \mathrm{~A}$ binding to heparin-agarose beads was tested by preincubating purified $\Delta \mathrm{TMgpK} 8.1 \mathrm{~A}$ with different concentrations of heparin for $1 \mathrm{~h}$ at $4^{\circ} \mathrm{C}$ and then incubating it with heparin-agarose beads for $2 \mathrm{~h}$ at $4^{\circ} \mathrm{C}$. These mixtures were washed five times. The bound materials were eluted by boiling the beads in sample buffer and analyzed by Western blotting with antigpK8.1A MAb.

Virion envelope-associated gpK8.1A binding with heparin-agarose. HHV-8 from TPA-induced BCBL-1 cells was purified by two cycles on a sucrose density gradient as per method described before (13). Purified virus was labeled with biotin according to the manufacturer's recommendations (Gibco-BRL), and the free biotin was removed by extensive dialysis against $0.5 \mathrm{M}$ sodium carbonate buffer ( $\mathrm{pH}$ 9.0) and then against PBS ( $\mathrm{pH}$ 7.4). The cell-binding activity of biotin-labeled virus was tested by SIFA as described above, and bound virus was detected by use of gpK8.1A MAb or FITC-labeled streptavidin. To test the binding activity with heparin-agarose, biotin-labeled purified HHV-8 was lysed with RIPA buffer, sonicated, and centrifuged at $100,000 \times g$ for $1 \mathrm{~h}$ at $4^{\circ} \mathrm{C}$. The resulting soluble biotinylated envelope protein supernatant was mixed with 100 $\mu \mathrm{l}$ of $50 \%$ slurry of heparin-agarose or agarose beads in RIPA buffer and mixed for $2 \mathrm{~h}$ at $4^{\circ} \mathrm{C}$. The beads were washed five times in RIPA buffer, boiled in sample buffer with 2-ME, resolved by SDS-10\% PAGE, Western blotted, and analyzed with anti-gpK8.1A MAb or with AP-conjugated streptavidin (Dako, Carpinteria, Calif.).

Purification of HHV-8 full-length gpK8.1A. Full-length gpK8.1A was purified using methods previously described (60). Briefly, TPA (Sigma, St. Louis, Mo.)induced BCBL-1 cells were lysed on ice for $1 \mathrm{~h}$ with lysis buffer $(10 \mathrm{mM}$ Tris- $\mathrm{HCl}$, $\mathrm{pH} 8.0 ; 140 \mathrm{mM} \mathrm{NaCl} ; 0.025 \% \mathrm{NaN}_{3} ; 2 \%$ Triton $\mathrm{X}-100 ; 1 \%$ sodium deoxycholate; $0.2 \mathrm{U}$ of aprotinin per $\mathrm{ml} ; 1 \mathrm{mM}$ phenylmethylsulfonyl fluoride). Cell lysates were passed over a column of Sepharose 4B covalently coupled with gpK8.1A-specific MAb 4D6 at $4^{\circ} \mathrm{C}$. The unbound proteins were removed by extensive washing with lysis buffer. The bound gpK8.1A was eluted with low-pH buffer $(50 \mathrm{mM}$ glycine- $\mathrm{HCl}[\mathrm{pH} 2.5]$ in $150 \mathrm{mM} \mathrm{NaCl}$ and $0.1 \% \mathrm{NP}-40)$ and immediately neutralized with a $1 / 10$ volume of $1 \mathrm{M}$ Tris- $\mathrm{HCl}(\mathrm{pH} 8.0)$. The peak fractions were pooled, dialyzed against $\mathrm{PBS}(\mathrm{pH} 7.0)$, and stored at $-70^{\circ} \mathrm{C}$.

\section{RESULTS}

HHV-8 envelope glycoprotein gpK8.1A binds to the target cells. The HHV-8 K8.1 gene encodes two ORFs, gpK8.1A and gpK8.1B, which are derived from spliced mRNAs (10). The gpK8.1A ORF is 228 aa long with a signal sequence and a transmembrane domain, consisting of a 167-aa region identical to gpK8.1B and a unique 61-aa region (Fig. 1A). The aminoterminal 142-aa region of gpK8.1A is identical to the 197-aa genomic K8.1 ORF with the splicing event generating the gpK8.1A ORF transmembrane domain absent in the genomic K8.1 ORF (Fig. 1A) (10). HHV-8 gpK8.1A is a virion envelope-associated immunogenic glycoprotein containing both $\mathrm{N}$ and O-linked sugars (60). MAbs against gpK8.1A recognized multiple proteins with molecular masses ranging from 34 to 72 $\mathrm{kDa}$ from BCBL-1 cells and 68 - to $72-\mathrm{kDa}$ proteins from the 
$\mathbf{A}$

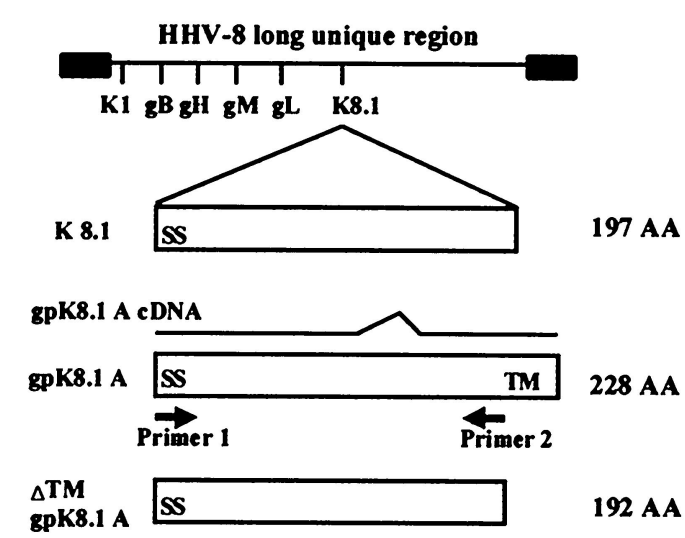

B



FIG. 1. (A) Construction of $\Delta \mathrm{TMgpK} 8.1 \mathrm{~A}$ without the transmembrane and carboxyl domains. The top line shows the schematic diagram of HHV-8 genome and the location of encoded glycoprotein ORFs. The genomic K8.1 ORF is 197 aa long with a signal sequence (SS) and without the transmembrane (TM) sequence. The 228-aa gpK8.1A ORF with signal and transmembrane sequences is derived from a spliced mRNA (10). The $\Delta \mathrm{TMgpK} 8.1 \mathrm{~A}$ was constructed by using primers amplifying aa 1 to 192 with the signal sequence but lacking the transmembrane and the carboxyl domains. (B) Expression and purification of $\Delta \mathrm{TMgpK} 8.1 \mathrm{~A}$ in the baculovirus expression system. Sf9 insect cells were infected with $\Delta$ TMgpK8.1A-baculovirus for 2 days and labeled with $\left[{ }^{35} \mathrm{~S}\right]$ methionine for $20 \mathrm{~h}$. His-tagged $\Delta \mathrm{TMgpK} 8.1 \mathrm{~A}$ protein from the cell pellet was purified by use of a nickel column. Protein purity was analyzed by SDS-12\% PAGE gels, Western blots with anti-gpK8.1 MAb, and autoradiography. Lane 1, full-length gpK8.1A affinity purified from HHV-8-infected BCBL-1 cells detected by Western blot reaction with anti-gpK8.1A MAb; lane 2, $\Delta \mathrm{TMgpK} 8.1 \mathrm{~A}$-expressing Sf9 insect cell lysate in Western blot reactions with anti-gpK8.1A MAb; lane 3, $\Delta \mathrm{TMgpK} 8.1 \mathrm{~A}$-expressing Sf9 cells culture supernatant in Western blot reactions with anti-gpK8.1A MAb; lane 4, $\left[{ }^{35}\right.$ S $]$ methionine-labeled purified $\Delta \mathrm{TMgpK} 8.1 \mathrm{~A}$ in Western blot reactions with anti-gpK8.1A MAb; lane 5, autoradiography of $\left[{ }^{35} \mathrm{~S}\right]$ methionine-labeled purified $\Delta \mathrm{TMgpK} 8.1 \mathrm{~A}$. The numbers on the left indicate the molecular masses (in kilodaltons) of the standard protein markers run in parallel lanes. The glycosylated forms of $\Delta \mathrm{TMgpK} 8.1 \mathrm{~A}$ are marked on the right.

virion particles (60). These multiple proteins represent the precursor and glycosylated forms of gpK8.1A (60).

Because of the similarity of gpK8.1A to EBV gp350/gp220 involved in target cell recognition, we examined the ability of HHV-8 gpK8.1A to interact with the target cells. The gpK8.1A was affinity purified from TPA-induced BCBL-1 cells (Fig. 1B, lane 1) (60). Paraformaldehyde-fixed BJAB, 293, or HFF cells were incubated with purified gpK8.1A, washed, and reacted with anti-gpK8.1A MAbs or MAbs against HHV-8 ORF 59 (11) or normal mouse IgG. After incubation and washing, the bound antibody was detected by incubating with FITC-labeled anti-mouse IgG in SIFAs. Cells treated with $0.1 \%$ paraformaldehyde were used in the binding assay, since this treatment allows the binding of protein but prevents the entry into cells (25). In addition, binding assays can be performed at $37^{\circ} \mathrm{C}(25)$. Fluorescence signals representing the cell bound gpK8.1A were detected on the membranes of BJAB or 293 or HFF cells, and the results with BJAB and 293 cells are shown in Fig. 2A and $\mathrm{B}$. No fluorescence signal was detected in cells incubated with anti-gpK8.1A MAbs only (Fig. 2C). Fluorescence signal was also not detected in cells incubated with ORF 59 MAbs or normal mouse $\mathrm{IgG}$ or rabbit antibodies against HHV-8 latency-associated ORF 73 protein (data not shown). Fluorescence signal was also not detected in cells incubated with His-tagged ORF 73 protein (data not shown). These results demonstrated the binding of gpK8.1A to the cell surface and suggested a role for gpK8.1A in the interaction between HHV-8 and the target cells.

Expression and purification of HHV-8 $\Delta$ TMgpK8.1A without transmembrane and cytoplasmic domains. Since only about $20 \%$ of TPA-induced BCBL-1 cells expressed HHV-8 lytic-cycle proteins, the yield of purified gpK8.1A by affinity chromatography was insufficient for binding studies. Hence, a 576-bp $\Delta \mathrm{TMgpK} 8.1 \mathrm{~A}$ gene region encoding aa 1 to 192 lacking the transmembrane and the carboxyl domains was amplified by PCR (Fig. 1A), cloned, and expressed in the baculovirus system. The $\Delta$ TMgpK8.1A-baculovirus-infected Sf9 cell pellets and the culture supernatant were analyzed in Western blot reactions with gpK8.1A-specific MAbs. The predicted molecular mass of unglycosylated $\Delta \mathrm{TMgpK} 8.1 \mathrm{~A}$ is about $21 \mathrm{kDa}$. MAbs recognized proteins ranging from 29 to $42 \mathrm{kDa}$ from the $\Delta$ TMgpK8.1A-baculovirus-infected Sf 9 cell pellets and culture supernatant (Fig. 1B, lanes 2 and 3). These proteins represent the different glycosylated forms of $\Delta$ TMgpK8.1A. The molecular masses of baculovirus-expressed $\Delta \mathrm{TMgpK}$.1A proteins (Fig. 1B, lanes 2 and 3) were smaller than the gpK8.1A from the BCBL-1 cells (Fig. 1B, lane 1). This could be due to the absence of 36 aa in $\triangle \mathrm{TMgpK} 8.1 \mathrm{~A}$, as well as to the differences in the efficiency of $\mathrm{N}$ and $\mathrm{O}$ glycosylation between insect and mammalian cells $(60,61)$. HHV-8 ORF 59 MAbs or normal mouse IgG did not react with $\Delta \mathrm{TMgpK} 8.1 \mathrm{~A}$ protein in Western blot reactions (data not shown).

Sf9 cells infected with $\Delta$ TMgpK8.1A-baculovirus were labeled with $\left[{ }^{35} \mathrm{~S}\right]$ methionine and radiolabeled $\Delta \mathrm{TMgpK} 8.1 \mathrm{~A}$ from the cell lysate was purified by use of nickel columns. The purity of the protein was analyzed by silver staining of SDSPAGE, Western blot reactions with anti-gpK8.1A MAb, and autoradiography. Fractions containing the purified protein were pooled, dialyzed, concentrated, and reanalyzed. Purified radiolabeled $\Delta \mathrm{TMgpK} 8.1 \mathrm{~A}$ proteins of about 32 to $42 \mathrm{kDa}$ were detected in the Western blot reactions and by autoradiography (Fig. 1B, lanes 4 and 5). Contaminating proteins 

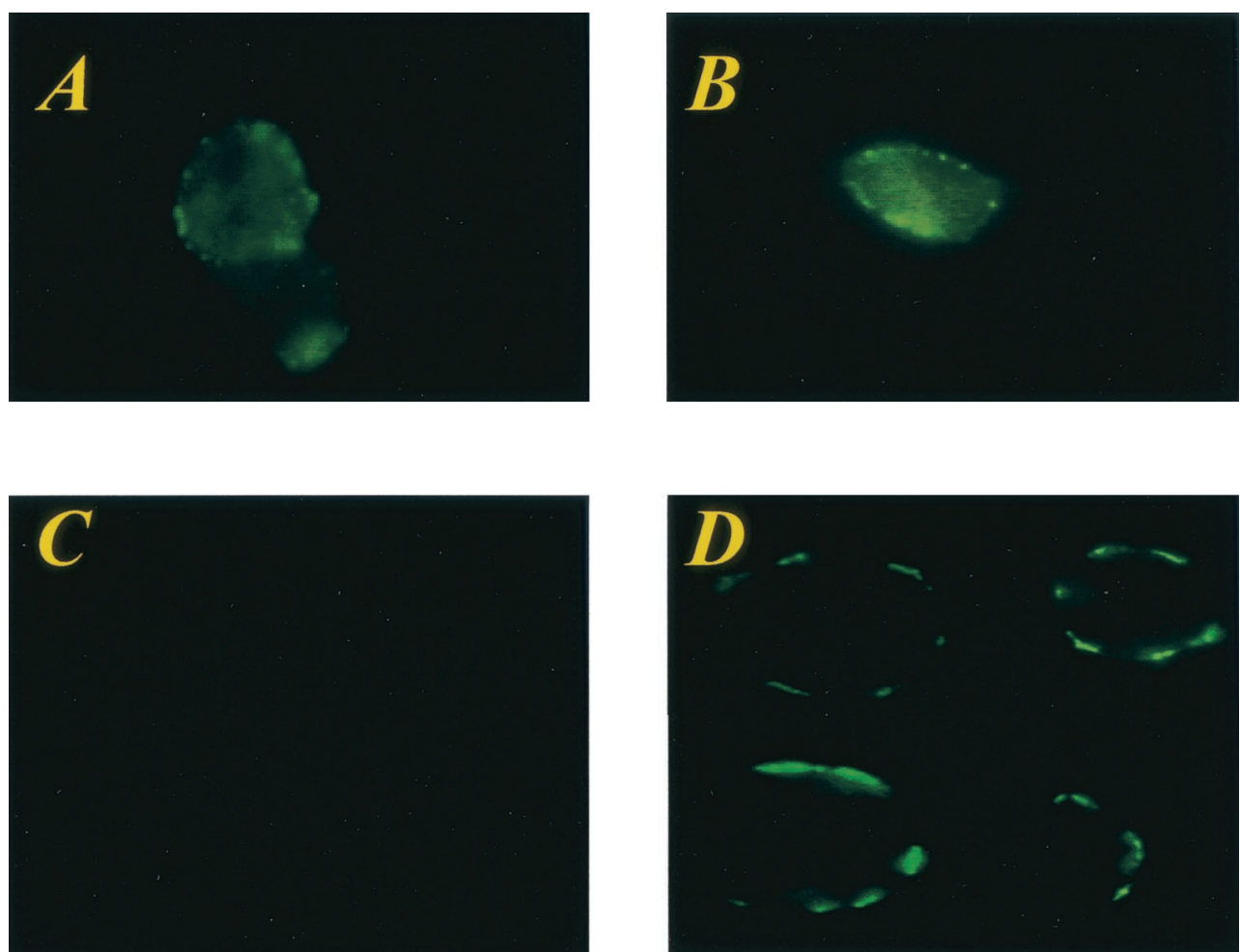

FIG. 2. HHV-8 gpK8.1A binds to the target cells. Binding of purified full-length gpK8.1A and $\Delta \mathrm{TMgpK} 8.1 \mathrm{~A}$ to the target cells was detected by surface immunofluorescence assay. Paraformaldehyde-treated BJAB, 293, HFF, or HMVEC-d cells were incubated with medium alone (controls) or medium with purified proteins for $30 \mathrm{~min}$ at $37^{\circ} \mathrm{C}$. After cells were washed, anti-gpK8.1A-specific MAb or anti-HHV-8 ORF $59 \mathrm{MAb}$ (11) or rabbit anti-HHV-8 ORF 73 antibodies (34) were added, incubated for $30 \mathrm{~min}$ at $37^{\circ} \mathrm{C}$, washed, and incubated for an additional 30 min at $37^{\circ} \mathrm{C}$ with FITC-conjugated goat anti-mouse or anti-rabbit IgG antibodies. Cells were washed, mounted, and examined under a fluorescence microscope. (A and B) BJAB and 293 cells, respectively, incubated with the full-length affinity-purified gpK8.1A and anti-gpK8.1A MAb. (C) BJAB cells incubated with anti-gpK8.1A MAb alone. (D) BJAB cells incubated with the purified His-tagged $\Delta \mathrm{TMgpK} 8.1 \mathrm{~A}$ and anti-gpK8.1A MAb. Fluorescence signals detected on the surface of cells indicate the cell-bound gpK8.1A and $\Delta \mathrm{TMgpK} 8.1 \mathrm{~A}$.

were not detected. We used the $\Delta \mathrm{TMgpK} 8.1 \mathrm{~A}$ protein purified from the Sf9 cell pellets in all subsequent assays, since only a limited quantity of $\Delta \mathrm{TMgpK} 8.1 \mathrm{~A}$ was detected in the infected Sf9 cell culture supernatant. This could be due to the weak cleavage of gpK8.1A signal sequence in the insect cells. A similar observation was made when HSV gD was expressed with the native signal sequence (48).

HHV-8 $\Delta$ TMgpK8.1A binds to the target cells. To determine whether $\Delta \mathrm{TMgpK} 8.1 \mathrm{~A}$ binds to the target cells, unlabeled purified $\Delta \mathrm{TMgpK} 8.1 \mathrm{~A}$ was allowed to bind the paraformaldehyde-treated BJAB, 293, HFF, or HMVEC-d cells, which were washed and tested with anti-gpK8.1A MAbs in SIFAs. Brightring-type fluorescence was observed only on cells incubated with $\Delta \mathrm{TMgpK} 8.1 \mathrm{~A}$, and the results with $\mathrm{BJAB}$ cells are shown in Fig. 2D. Binding was not detected when cells were incubated with purified His-tagged ORF 73 protein (data not shown). These data further confirm the interaction of gpK8.1A with the cell surface and show that the extracellular domains of gpK8.1A mediate this binding.

To quantitate the target cell bindings, purified $\left[{ }^{35} \mathrm{~S}\right]$ methionine-labeled $\Delta \mathrm{TMgpK} 8.1 \mathrm{~A}(7,666 \mathrm{cpm} / \mu \mathrm{g}$ of protein) was incubated with HFF, BJAB, 293, and HMVEC-d cells. Radiolabeled $\Delta \mathrm{TMgpK} 8.1 \mathrm{~A}$ bound to all cells in a dose-dependent manner, and the results with HFF cells are shown in Fig. 3A. Similar results were observed when binding assays were per- formed with untreated cells at $4^{\circ} \mathrm{C}$ or with paraformaldehydetreated cells at $37^{\circ} \mathrm{C}$. The results with untreated cells at $4^{\circ} \mathrm{C}$ are presented here. Binding was not detected when the cells were incubated with $\left[{ }^{35} \mathrm{~S}\right] \mathrm{methionine}-$ labeled $(14,672 \mathrm{cpm} / \mu \mathrm{g}$ of protein) purified His-tagged HHV-8 latency-associated ORF 73 protein (Fig. 3A).

To determine the specificity of $\Delta \mathrm{TMgpK} 8.1 \mathrm{~A}$ binding, homologous competition assays were done. HFF cells were preincubated for $15 \mathrm{~min}$ at $4^{\circ} \mathrm{C}$ with different concentrations of unlabeled $\Delta$ TMK8.1A and then incubated with a fixed concentration (3.5 and $15 \mu \mathrm{g}$ for the 96- and 24-well plates, respectively) of purified radiolabeled $\Delta \mathrm{TMgpK} 8.1 \mathrm{~A}(7,666 \mathrm{cpm} / \mu \mathrm{g}$ of protein). Similar results were observed with untreated cells at $4^{\circ} \mathrm{C}$ or with paraformaldehyde-treated cells at $37^{\circ} \mathrm{C}$. The results with untreated cells in 96 -well plates at $4^{\circ} \mathrm{C}$ are presented in Fig. $3 \mathrm{~B}$. In the absence of unlabeled $\Delta \mathrm{TMgpK} 8.1 \mathrm{~A}$ protein, about $30 \%$ of the input labeled $\Delta$ TMgpK8.1A (1.1 and $4.5 \mu \mathrm{g}$ for cells in the 96- and 24-well plates, respectively) became associated with the cells. The binding of labeled protein was inhibited in a dose-dependent manner by the preincubation with unlabeled $\Delta \mathrm{TMgpK} 8.1 \mathrm{~A}$, demonstrating the specificity of labeled $\Delta \mathrm{TMgpK} 8.1 \mathrm{~A}$ interactions with the cell surface.

Purified $\triangle$ TMgpK8.1A blocks HHV-8 binding to the target cells. To determine if the interaction of gpK8.1A with the cell surfaces is biologically relevant, the ability of purified nonra- 
A

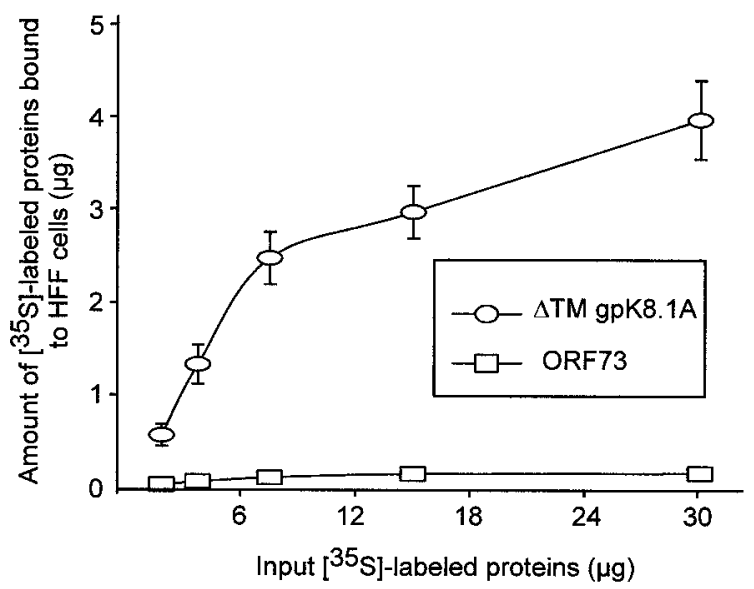

$\mathbf{B}$

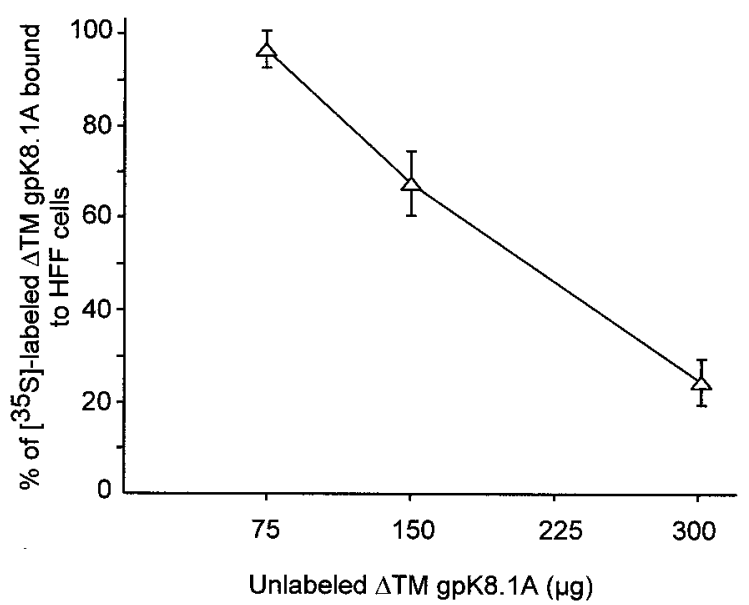

FIG. 3. (A) Binding of radiolabeled $\Delta$ TMgpK8.1A to HFF cells. Different concentrations of $\left[{ }^{35} \mathrm{~S}\right]$ methionine-labeled purified $\Delta \mathrm{TMgpK} 8.1 \mathrm{~A}$ $(7,666 \mathrm{cpm} / \mu \mathrm{g}$ of protein) or ORF $73(14,672 \mathrm{cpm} / \mu \mathrm{g}$ of protein) proteins were incubated for $90 \mathrm{~min}$ at $4^{\circ} \mathrm{C}$ with HFF cells in 96- or 24-well plates. After incubation, cells were washed five times and lysed with $1 \%$ SDS and $1 \%$ Triton X-100, and the cell-bound $\Delta$ TMgpK8.1A radioactivity was counted. Each reaction was done in triplicate and each point represents the average \pm the standard deviation (SD) of three experiments. Similar results were seen with cells in 96- and 24-well plates, and the results with the 96-well plates are shown here. (B) Inhibition of labeled $\Delta$ TMK8.1A binding to cells by unlabeled $\Delta$ TMK8.1A protein. HFF cells were preincubated with the indicated concentrations of nonlabeled $\Delta \mathrm{TMgpK} 8.1 \mathrm{~A}$ for $15 \mathrm{~min}$ and then incubated with $3.5 \mu \mathrm{g}$ (for cells in the 96-well plate) or $15 \mu \mathrm{g}$ (for cells in the 24-well plate) of ${ }^{35} \mathrm{~S}$-labeled $\Delta \mathrm{TMgpK} 8.1 \mathrm{~A}(7,666 \mathrm{cpm} / \mu \mathrm{g}$ of protein) for $90 \mathrm{~min}$ at $4{ }^{\circ} \mathrm{C}$. Cells were washed five times and lysed with $1 \%$ SDS and $1 \%$ Trition $\mathrm{X}-100$, and the cell-bound $\Delta \mathrm{TMgpK} 8.1 \mathrm{~A}$ radioactivity was counted. The cell-associated radiolabeled $\Delta \mathrm{TMgpK} 8.1 \mathrm{~A}$ $\mathrm{cpm}$ in the presence or absence of unlabeled protein was calculated. In the absence of unlabeled $\Delta \mathrm{TMgpK} 8.1 \mathrm{~A}$ protein, about $30 \%$ of the input labeled $\Delta \mathrm{TMgpK} 8.1 \mathrm{~A}$ (1.1 and $4.5 \mu \mathrm{g}$ for cells in the 96-well and 24-well plates, respectively) became associated with the cells. Each reaction was done in triplicate, and each point represents the average \pm the SD of three experiments.



FIG. 4. Nonradiolabeled $\Delta$ TMgpK8.1A blocks HHV-8 attachment. HFF cells were incubated with increasing concentrations of purified unlabeled $\Delta \mathrm{TMgpK} 8.1 \mathrm{~A}$ for $90 \mathrm{~min}$ at $4^{\circ} \mathrm{C}$, followed by the addition of a fixed quantity of $\left[{ }^{3} \mathrm{H}\right]$ thymidine-labeled purified HHV-8 $(2,684 \mathrm{cpm})$ (2). For a control, a fixed quantity of $\left[{ }^{3} \mathrm{H}\right]$ thymidine-labeled purified HHV-8 (2,684 cpm) was mixed with $10 \mu \mathrm{g}$ of heparin per $\mathrm{ml}$ for $90 \mathrm{~min}$ at $4^{\circ} \mathrm{C}$ and then added to $\mathrm{HFF}$ cells. After incubation for $90 \mathrm{~min}$ at $4{ }^{\circ} \mathrm{C}$ with the virus, cells were washed five times and lysed with $1 \%$ SDS and $1 \%$ Triton X-100, and the radioactivity was precipitated with TCA and counted. The cell-associated virus cpm in the absence or presence of unlabeled $\Delta \mathrm{TMgpK} 8.1 \mathrm{~A}$ and heparin and the percentage of inhibition of virus binding were calculated. In the absence of heparin or $\Delta$ TMgpK $8.1 \mathrm{~A}$, approximately $21 \%$ of the input HHV-8 radioactivity (552 cpm) became associated with the cells. Approximately $90 \%$ of HHV-8 attachment to the cells was blocked by heparin. Each reaction was done in triplicate, and each point represents the average \pm the SD of three experiments.

diolabeled $\Delta$ TMgpK8.1A to complete with $\left[{ }^{3} \mathrm{H}\right]$ thymidine-labeled HHV-8 binding to HFF cells was examined. HFF cells were preincubated with increasing concentrations of purified unlabeled $\triangle \mathrm{TMK} 8.1 \mathrm{~A}$ for $90 \mathrm{~min}$ at $4^{\circ} \mathrm{C}$, followed by a constant quantity of $\left[{ }^{3} \mathrm{H}\right]$ thymidine-labeled purified HHV-8 $(2,684$ $\mathrm{cpm}$ ), which is within the linear range of the dose-response curve (2). As a control for these experiments, a constant quantity of $\left[{ }^{3} \mathrm{H}\right]$ thymidine-labeled purified HHV-8 $(2,684 \mathrm{cpm})$ was incubated with $10 \mu \mathrm{g}$ of heparin per $\mathrm{ml}$ for $90 \mathrm{~min}$ at $4^{\circ} \mathrm{C}$ and then added to HFF cells. In the absence of heparin or unlabeled $\Delta \mathrm{TMgpK} 8.1 \mathrm{~A}$ protein, approximately $21 \%$ of the input HHV-8 radioactivity became associated with the cells. As in to our earlier observation (2), $10 \mu \mathrm{g}$ of heparin blocked approximately $90 \%$ of HHV-8 attachment to the cells (data not shown). HHV-8 adsorption was also blocked by the unlabeled purified $\Delta$ TMgpK8.1A in a dose-dependent fashion (Fig. 4). HHV-8 binding was diminished by approximately $70 \%$ compared to the untreated control (Fig. 4). Treatment of cells with identical concentrations of BSA or ORF 73 protein had no effect on virus binding, suggesting that the block in HHV-8 binding was probably to the engagement of a necessary HHV-8 cellular receptor by gpK8.1A and was not simply due to protein-protein interference. This suggested that gpK8.1A occupied cell surface molecule(s) that functions as an HHV-8 attachment receptor.

Heparin blocks HHV-8 $\triangle$ TMgpK8.1A binding to the target cells. Heparin is closely related to HS, and inhibition of virus infectivity by heparin treatment has been considered as an 
evidence for alpha-, beta-, and gamma-2-herpesvirus interaction with cell surface HS molecules $(21,24,30,31,33,35,37$, 46-47, 49, 51, 57). Our recent studies showed that HHV-8 interaction with host cell surface involved HS and soluble heparin prevented HHV-8 infectivity (2). To determine whether heparin inhibits $\Delta \mathrm{TMgpK} 8.1 \mathrm{~A}$ binding, a constant quantity of purified radiolabeled $\Delta \mathrm{TMgpK} 8.1 \mathrm{~A}$ within the linear range of the dose-response curve (3.5 $\mu \mathrm{g}$ for cells in 96-well plates or 15 $\mu \mathrm{g}$ for cells in 24-well plates) (Fig. 3A) was mixed with medium alone or medium with different concentrations of heparin and incubated at $4^{\circ} \mathrm{C}$ for $90 \mathrm{~min}$. These were then added to the paraformaldehyde-treated target cells and incubated at $37^{\circ} \mathrm{C}$ for $90 \mathrm{~min}$ or to the untreated target cells and incubated at $4^{\circ} \mathrm{C}$ for $90 \mathrm{~min}$. After incubation, cells were washed five times and cell-associated $\Delta$ TMgpK8.1A cpm values were counted. Similar results were observed when binding assays were performed at 4 or at $37^{\circ} \mathrm{C}$, and results with untreated cells $4^{\circ} \mathrm{C}$ are shown in Fig. 5A.

In the absence of heparin, approximately $30 \%$ of the input $\Delta \mathrm{TMgpK} 8.1 \mathrm{~A}$ radioactivity became associated with the cells. Soluble heparin significantly inhibited the binding of labeled $\Delta$ TMgpK8.1A to all cell lines tested in a dose-dependent manner. The results with HFF cells and HMVEC-d cells are shown in Fig. 5A. The percentage of inhibition plateaued at between 1 and $10 \mu \mathrm{g}$ of heparin per ml for HFF and HMVEC cells (Fig. 5A) and for 293 cells (data not shown), and the maximum inhibition ranged from 83 to $95 \%$. The specificity of heparin inhibition was shown by the absence of inhibition by CS-A and CS-C, even at a concentration of $100 \mu \mathrm{g} / \mathrm{ml}$. CS-B also inhibited $\Delta \mathrm{TMgpK} 8.1 \mathrm{~A}$ binding to the cell surface, with about 30 and $70 \%$ inhibition at concentrations of 10 and $100 \mu \mathrm{g} / \mathrm{ml}$, respectively (Fig. 5A). However, these CS-B concentrations required to inhibit $50 \%$ of $\Delta \mathrm{TMgpK} 8.1 \mathrm{~A}$ binding to the cell surface were almost 100 times higher than that of the required heparin concentration. The inhibition of $\Delta \mathrm{TMgpK} 8.1 \mathrm{~A}$ binding to the target cells by heparin even at a low concentration suggested that $\Delta \mathrm{TMgpK} 8.1 \mathrm{~A}$ interacts with the cell surface HS. The inability of heparin to completely prevent the protein binding suggests that gpK8.1A also binds to other host cell molecules.

Displacement of cell surface adsorbed HHV-8 $\Delta \mathrm{TMgpK8.1A}$ by heparin. To determine the specificity of HHV-8 $\Delta$ TMgpK8.1A interaction with cell surface HS and the inhibition by heparin, labeled $\Delta \mathrm{TMgpK} 8.1$ was first allowed to adsorb to the HFF cells and at different times postadsorption, heparin or CS-A, $-\mathrm{B}$, or $-\mathrm{C}$ were added to a final concentration of $10 \mu \mathrm{g} / \mathrm{ml}$. Cells were further incubated for a total period of $90 \mathrm{~min}$, and the cell-associated radioactivity was counted. Similar results were observed when binding assays were performed with paraformaldehyde-treated cells at $37^{\circ} \mathrm{C}$ or with untreated cells at $4^{\circ} \mathrm{C}$. The results with untreated cells at $4^{\circ} \mathrm{C}$ are shown in Fig. 5. Pretreatment of HFF cells with heparin did not affect $\Delta$ TMgpK8.1 binding (data not shown). In the absence of heparin, about $30 \%$ of the input labeled $\Delta \mathrm{TMgpK} 8.1 \mathrm{~A}(1.1 \mu \mathrm{g})$ became associated with the cells. In contrast, when heparin was added to the $\Delta \mathrm{TMgpK} 8.1 \mathrm{~A}$ protein-cell mixture, it was capable of displacing already-adsorbed $\Delta \mathrm{TMgpK} 81 \mathrm{~A}$ even when added $40 \mathrm{~min}$ after the protein addition to the cells (Fig. 5B). The partial reversal of binding by the addition of heparin after 50 min of protein-cell interaction (Fig. 5B) could be due to the
A



B

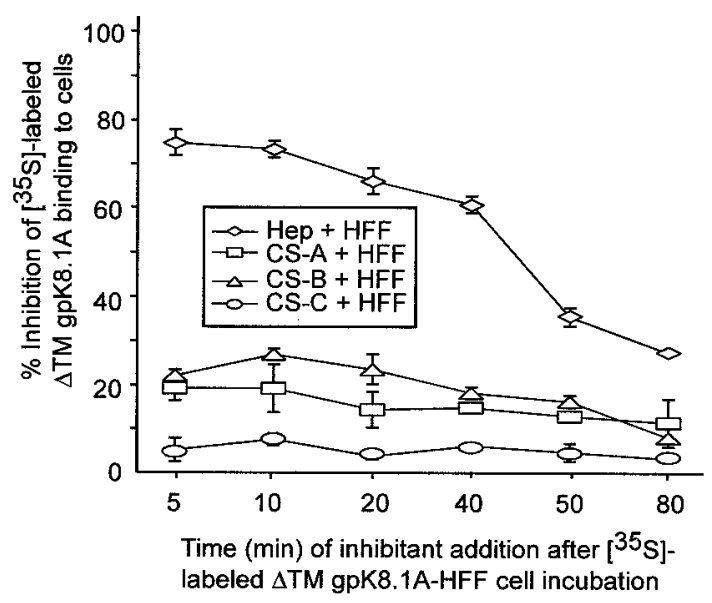

FIG. 5. Inhibition of $\left[{ }^{35} \mathrm{~S}\right]$ methionine-labeled purified $\Delta \mathrm{TMgpK} 8.1 \mathrm{~A}$ binding to target cells by heparin. (A) A constant quantity of purified labeled $\Delta \mathrm{TMgpK} 8.1 \mathrm{~A}(7,666 \mathrm{cpm} / \mu \mathrm{g}$ of protein) within the linear range of the dose-response curve $(3.5 \mu \mathrm{g}$ for cells in the 96 -well plate or $15 \mu \mathrm{g}$ for cells in the 24-well plate) (Fig. 3A) was mixed with medium alone or with different concentrations of heparin or CS-A, $\mathrm{CS}-\mathrm{B}$, or CS-C and then incubated for $90 \mathrm{~min}$ at $4^{\circ} \mathrm{C}$. These mixtures were then incubated with HFF or adult HMVEC-d (Endo) for $90 \mathrm{~min}$ at $4^{\circ} \mathrm{C}$ and washed five times. Cells were lysed with $1 \%$ SDS-1\% Triton $\mathrm{X}-100$ and counted. The cell-associated $\Delta \mathrm{TMgpK} 8.1 \mathrm{~A} \mathrm{cpm}$ in the presence or absence of heparin and the percentage of inhibition of $\Delta$ TMgpK8.1A binding were calculated. In the absence of heparin, approximately $30 \%$ of the input $\Delta \mathrm{TMgpK} 8.1 \mathrm{~A}$ radioactivity (1.1 and $4.5 \mu \mathrm{g}$ for cells in the 96-well and 24-well plates, respectively) became associated with the cells. Each reaction was done in triplicate and each point represents the average \pm the SD of three experiments. (B) Displacement of adsorbed $\Delta$ TMgpK8.1A from the HFF cell surface by heparin. HFF cell. monolayers in 96-well plates were incubated with a constant quantity $(3.5 \mu \mathrm{g})$ of purified labeled $\Delta \mathrm{TMgpK} 8.1 \mathrm{~A}(7,666$ $\mathrm{cpm} / \mu \mathrm{g}$ of protein). At the indicated time points, cells were incubated with medium (controls) or with medium containing $10 \mu \mathrm{g}$ of heparin or CS-A, CS-B, or CS-C per ml. Cells were further incubated for a total of $90 \mathrm{~min}$ at $4^{\circ} \mathrm{C}$, washed five times, and then counted. The cellassociated $\Delta \mathrm{TMgpK} 8.1 \mathrm{~A} \mathrm{cpm}$ in the presence or absence of heparin and the percentage of inhibition of $\Delta \mathrm{TMgpK} 8.1 \mathrm{~A}$ binding were calculated. In the absence of heparin, approximately $30 \%$ of the input $\Delta$ TMgpK8.1A radioactivity $(1.1 \mu \mathrm{g})$ became associated with the cells. Each reaction was done in triplicate, and each point represents the average \pm the $\mathrm{SD}$ of three experiments. 


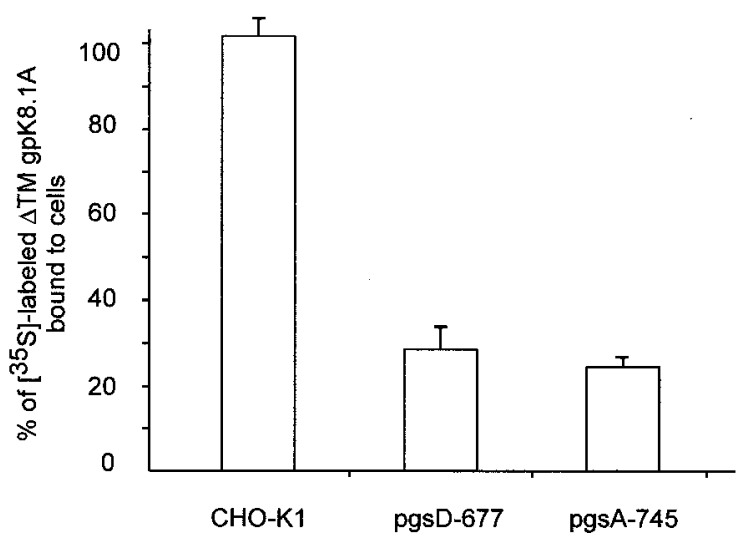

FIG. 6. Binding of radiolabeled $\Delta \mathrm{TMgpK} 8.1 \mathrm{~A}$ to CHO-K1 cells. Confluent monolayers of wild-type $\mathrm{CHO}-\mathrm{K} 1$ cells and of two $\mathrm{CHO}$ mutants, pgsD-677 (lacking HS but not chondroitin sulfate) and pgsA745 (lacking both HS and chondroitin sulfate), in 24-well plates were incubated with $15 \mu \mathrm{g}$ of $\left[{ }^{35} \mathrm{~S}\right]$ methionine-labeled purified $\Delta \mathrm{TMgpK} 8.1 \mathrm{~A}$ $\left(3,310 \mathrm{cpm} / \mu \mathrm{g}\right.$ of protein) for $90 \mathrm{~min}$ at $4^{\circ} \mathrm{C}$. The cells were washed five times and lysed in 1\% SDS-1\% Triton X-100, and the cell-associated radioactivity was counted. About $4 \mu \mathrm{g}$ or $26 \%$ of the input $\Delta$ TMgpK8.1A radioactivity bound to $\mathrm{CHO}-\mathrm{K} 1$ cells. The results are expressed as the percentage of radioactivity bound to the wild-type $\mathrm{CHO}-\mathrm{K} 1$ cells. Each reaction was done in triplicate, and each point represents the average \pm the SD of three experiments.

onset of interactions between gpK8.1A and cellular receptors other than HS molecules. Reversal of $\Delta \mathrm{TMgpK} 8.1 \mathrm{~A}$ binding to the cells by heparin demonstrated the specificity of HS interaction with HHV-8 gpK8.1A. Specificity was also shown by the absence of any significant inhibition by the same amount (10 $\mu \mathrm{g} / \mathrm{ml}$ ) of CS-A, -B, and -C (Fig. 5B).

HHV-8 $\Delta$ TMgpK8.1A binds to the HS-expressing CHO-K1 cell line but not to cells lacking HS. To verify the role of HS in the attachment of $\Delta \mathrm{TMgpK} 8.1 \mathrm{~A}$ to the target cells, binding assays were done with wild-type CHO-K1 cell line expressing HS and its two mutant cell lines, pgsD-677 cells (deficient in HS but not in chondroitin sulfate) and pgsA-745 cells (deficient in both HS and chondroitin sulfate). Radiolabeled $\Delta \mathrm{TMgpK} 8.1 \mathrm{~A}(3,310 \mathrm{cpm} / \mu \mathrm{g}$ of protein) bound readily to the wild-type $\mathrm{CHO}-\mathrm{K} 1$ cells to the same extent as HFF cells. About $4 \mu \mathrm{g}$ or $26 \%$ of the input labeled $\Delta \mathrm{TMgpK} 8.1 \mathrm{~A}$ became associated with the CHO-K1 cells (Fig. 6). In contrast, $\Delta \mathrm{TMgpK} 8.1 \mathrm{~A}$ binding to the mutant cells was significantly impaired, and about fivefold-less binding was detected with the pgsD-677 and pgsA-745 cells (Fig. 6). These results confirmed the interaction of HHV-8 $\Delta \mathrm{TMgpK} 8.1 \mathrm{~A}$ with the cell surface HS. The low percentage of $\Delta \mathrm{TMgpK} 8.1 \mathrm{~A}$ binding to the cells lacking HS further supported the notion that gpK8.1A also probably binds other host cell molecules.

HHV-8 $\Delta$ TMgpK8.1A specifically binds to heparin. To verify the specificity of gpK8.1A binding to HS, the ability of $\Delta$ TMgpK8.1A to bind the heparin-agarose beads was tested. Purified $\Delta$ TMgpK8.1A, HHV-8 gL, or HHV-8 ORF 73 (2.5 $\mu \mathrm{g})$ protein was incubated with heparin-agarose beads. After an extensive washing, the beads were boiled in sample buffer. The eluted proteins were detected by immunoblot using antigpK8.1A MAb, rabbit anti-gL antibodies, and rabbit anti-ORF 73 antibodies. Representative results are presented in Fig. 7.
A

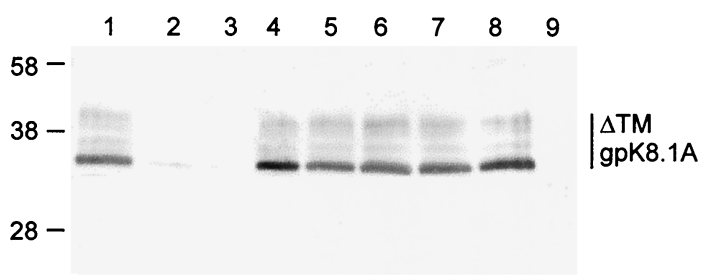

B

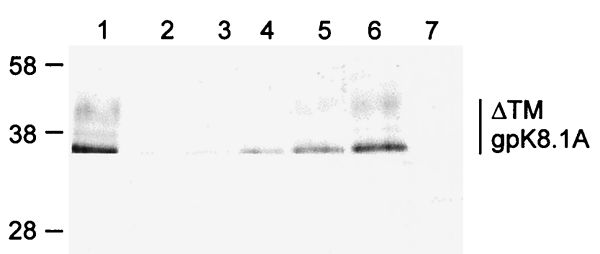

FIG. 7. (A) HHV-8 $\Delta$ TMgpK8.1A binding to heparin-agarose beads. Purified $\Delta$ TMgpK8.1A $(2.5 \mu \mathrm{g})$ was incubated with or without $350 \mu \mathrm{g}$ of various GAGs for $1 \mathrm{~h}$ at $4^{\circ} \mathrm{C}$ and then with heparin-agarose beads for $2 \mathrm{~h}$ at $4^{\circ} \mathrm{C}$. These mixtures were washed five times, and bound material was eluted by boiling in sample buffer, analyzed by SDS- $12 \%$ PAGE gels, and tested with anti-gpK8.1A MAb in Western blot reactions. Lane 1, purified $\triangle \mathrm{TMgpK} 8.1 \mathrm{~A}$ with heparin-agarose beads; lanes 2 to 8 , purified $\Delta \mathrm{TMgpK} 8.1 \mathrm{~A}$ preincubated with heparin (lane 2), HS (lane 3), CS-A (lane 4), CS-B (lane 5), CS-C (lane 6), $N$-acetyl heparin (lane 7), and de- $N$-sulfated heparin (lane 8) before the addition of heparin-agarose beads; lane 9, purified $\Delta$ TMgpK8.1A with agarose beads. The numbers on the left indicate the molecular masses (in kilodaltons) of the standard protein markers run in parallel lanes. The glycosylated forms of $\Delta \mathrm{TMgpK} 8.1 \mathrm{~A}$ are marked on the right. (B) Dose-response results of heparin blocking HHV-8 $\Delta \mathrm{TMgpK} 8.1 \mathrm{~A}$ binding to heparin-agarose beads. Purified $\Delta \mathrm{TMgpK} 8.1 \mathrm{~A}(2.5 \mu \mathrm{g})$ was preincubated with different concentrations of heparin for $1 \mathrm{~h}$ at $4^{\circ} \mathrm{C}$ and then incubated with heparin-agarose beads for $2 \mathrm{~h}$ at $4^{\circ} \mathrm{C}$. These mixtures were washed five times, and bound material was eluted by boiling the beads in sample buffer and then analyzed by SDS-12\% PAGE gels and in Western blot reactions with anti-gpK8.1A MAb. Lane 1, purified $\Delta \mathrm{TMgpK} 8.1 \mathrm{~A}$ with heparin-agarose beads; lanes 2 to 7 , purified $\Delta$ TMgpK8.1A preincubated with $300 \mu \mathrm{g}$ (lane 2), $150 \mu \mathrm{g}$ (lane 3), $75 \mu \mathrm{g}$ (lane 4), $38 \mu \mathrm{g}$ (lane 5), or $19 \mu \mathrm{g}$ (lane 6) of heparin before the addition of heparin-agarose beads; lane 7, purified $\Delta$ TMgpK8.1A with agarose beads. The numbers on the left indicate the molecular masses (in kilodaltons) of the standard protein markers run in parallel lanes. The glycosylated forms of $\Delta \mathrm{TMgpK} 8.1 \mathrm{~A}$ are marked on the right.

HHV-8 gL and ORF 73 proteins were not precipitated by heparin-agarose beads (data not shown). In contrast, heparinagarose beads precipitated the various glycosylated forms of $\Delta$ TMgpK8.1A (Fig. 7A, lane 1). To determine the specificity of this reaction, various GAGs were tested to compete with the heparin-agarose binding activity of $\Delta \mathrm{TMgpK} 8.1 \mathrm{~A}$. Heparin-agarose binding activity of $\Delta \mathrm{TMgpK} 8.1 \mathrm{~A}$ was competitively inhibited by preincubating the protein with $350 \mu \mathrm{g}$ of heparin (Fig. $7 \mathrm{~A}$, lane 2) or $350 \mu \mathrm{g}$ of $\mathrm{HS}$ (Fig. 7A, lane 3). In contrast, 350 $\mu \mathrm{g}$ of $\mathrm{CS}-\mathrm{A},-\mathrm{B}$, and -C, $N$-acetyl heparin, and de- $N$-sulfated heparin did not inhibit the $\Delta \mathrm{TMgpK} 8.1$ interaction with the heparin-agarose beads (Fig. 7A, lanes 4 to 8 ). No reactivity was seen with agarose beads alone (Fig. 7A, lane 9), thus demonstrating the specificity of these reactions. These results confirmed the interaction of gpK8.1A with HS and heparin. 
The specificity of HHV-8 $\Delta$ TMgpK8.1A binding to heparinagarose beads was also examined by preincubating $2.5 \mu \mathrm{g}$ of purified $\Delta \mathrm{TMgpK} 8.1 \mathrm{~A}$ with different concentrations of heparin for $1 \mathrm{~h}$ at $4^{\circ} \mathrm{C}$ and then incubating this with heparin-agarose beads for $2 \mathrm{~h}$ at $4^{\circ} \mathrm{C}$. No reactivity was seen when agarose beads were incubated with purified $\Delta \mathrm{TMgpK} 8.1 \mathrm{~A}$ (Fig. 7B, lane 7). Heparin-agarose beads precipitated the various glycosylated forms of $\Delta \mathrm{TMgpK} 8.1 \mathrm{~A}$ (Fig. 7B, lane 1). This binding was completely inhibited by the preincubation with heparin at a concentration of 300 and $150 \mu \mathrm{g}$ (Fig. 7B, lanes 2 and 3). Only moderate inhibition was seen with 75 and $38 \mu \mathrm{g}$ of heparin (Fig. 7B, lanes 4 and 5), and no inhibition was seen with $19 \mu \mathrm{g}$ of heparin (Fig. 7B, lane 6). These results further verified the interaction of gpK8.1A with HS and heparin.

Virion envelope-associated gpK8.1A binds heparin-agarose. To determine whether virion envelope associated gpK8.1A binds heparin-agarose, density gradient-purified HHV-8 was labeled with biotin. The biotinylated virus bound to the target cells in the surface immunofluorescence assay (data not shown). Similar to our earlier findings (60), gpK8.1A MAbs recognized the 68- to 72-kDa protein in Western blot reactions with purified HHV-8 (Fig. 8, lane 1). Biotinylated purified virus was lysed with RIPA buffer, sonicated, and centrifuged at $100,000 \times g$. The resulting supernatant containing the soluble biotinylated envelope proteins was mixed with heparin-agarose or agarose beads for $2 \mathrm{~h}$ at $4^{\circ} \mathrm{C}$ and washed. The bound material was eluted by boiling in sample buffer, resolved by SDSPAGE, Western blotted, and analyzed with AP-labeled streptavidin and substrate. Polypeptides of about 30 to $45 \mathrm{kDa}$ precipitated both by agarose and by heparin-agarose were considered nonspecific bands (Fig. 8, lanes 2 and 3). Polypeptides of ca. 75,72 , and $54 \mathrm{kDa}$ were specifically precipitated by heparin-agarose beads only (Fig. 8, lane 3). Preincubation of soluble biotinylated proteins with $350 \mu \mathrm{g}$ of heparin or HS prevented the interaction of these specific proteins with heparin-agarose beads (data not shown). When the proteins precipitated by heparin-agarose beads were reacted with antigpK8.1A MAbs in the Western blots, only the 72-kDa protein was specifically recognized (Fig. 8, lane 4), and no reactivity was seen with agarose bead-precipitated proteins (data not shown). No reaction was seen when proteins precipitated by heparin-agarose beads were reacted with rabbit anti-gL IgG antibodies (Fig. 8, lane 5). The identity of the heparin-agarose interacting 75- and 54-kDa HHV-8 envelope glycoproteins is under investigation. These results demonstrated the ability of virion envelope-associated gpK8.1A to interact with heparinagarose and thus HS.

\section{DISCUSSION}

Proteoglycans are found abundantly in the extracellular matrices or cell surfaces of animal cells and mediate many fundamental cellular processes, including cell-to-cell and cell-tomatrix adhesion, motility, growth, and signaling (28). A proteoglycan is formed by the linkage of glycosaminoglycans such as HS or chondroitin sulfate to a protein core. HS is the initial binding target of many microorganisms, including parasites, bacteria, and viruses $(23,42,54)$. Several alphaherpesviruses, such as HSV-1, HSV-2, PRV, and BHV-1 (21, 24, 30, 31, $33,46,47,51,59)$, betaherpesviruses, such as HCMV and

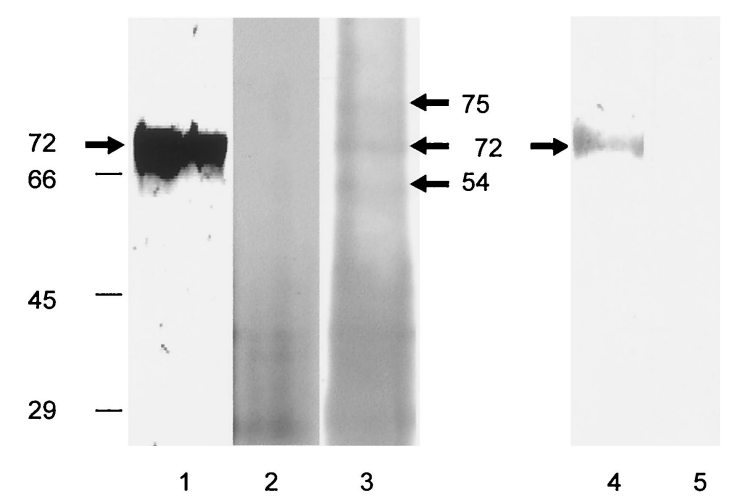

FIG. 8. Virion envelope-associated gpK8.1A binding with heparinagarose. Biotin-labeled purified HHV-8 was lysed with RIPA buffer, sonicated, and centrifuged at $100,000 \times g$ for $1 \mathrm{~h}$ at $4^{\circ} \mathrm{C}$. The resulting supernatant containing soluble biotinylated envelope proteins was mixed with heparin-agarose or agarose beads, mixed for $2 \mathrm{~h}$ at $4^{\circ} \mathrm{C}$, and washed five times in RIPA buffer. The bound material was eluted by boiling the beads in sample buffer with 2-ME, resolved by SDS-12\% PAGE, Western blotted, and analyzed. Lane 1, purified virus solubilized by sample buffer in Western blot reactions with anti-gpK8.1A $\mathrm{MAb}$; lane 2, biotinylated proteins eluted from the agarose beads reacted with AP-labeled streptavidin and substrate; lane 3, biotinylated proteins eluted from the heparin-agarose beads reacted with AP-labeled streptavidin and substrate; lane 4, biotinylated proteins eluted from the heparin-agarose beads in Western blot reactions with antigpK8.1A MAb; lane 5, biotinylated proteins eluted from the heparinagarose beads in Western blot reactions with rabbit anti-HHV-8 gL IgG antibodies. The numbers on the left indicate the molecular masses (in kilodaltons) of the standard protein markers run in parallel lanes.

HHV-7 (35, 37, 45, 49), and gamma-2-herpesviruses, such as BHV-4 (57), interact specifically with HS-like moieties. HS is also recognized by a wide spectrum of other viruses such as human immunodeficiency virus type $1(38,41)$, vaccinia virus (14), Sindbis virus (7), foot-and-mouth-disease virus (26), respiratory syncytial virus $(19,29)$, and adeno-associated virus (55).

Our recent studies show that the gamma-2-HHV-8, like some members of the alpha-, beta-, and gamma-2-herpesviruses, adsorbs to cells by binding to cell surface HS-like moieties (2). Studies here examined the role of HHV-8 envelope glycoprotein gpK8.1A in the interaction with target cells. Comparison with the human or animal herpesvirus sequences to date show that the gpK8.1A gene is unique for HHV-8. The location of the gpK8.1A gene in the genome clearly suggests an important role of gpK8.1A in the biology of HHV-8. The gpK8.1A gene is positionally colinear to the gamma-1-EBV gp350/gp220 gene (22), the gamma-2-MHV-68 gp150 gene (53), and the gamma-2-HVS ORF 51 gene (1). HHV-8 gpK8.1A shows several similarities with these proteins. Like EBV gp350/gp220 (56) and MHV-68 gp150 (53), HHV-8 gpK8.1A is a virion envelope- and infected cell membraneassociated glycoprotein (60). Antibodies against gp350/220 of EBV and gp150 MHV-68 neutralized the respective virus infectivities $(53,56)$. Binding of gpK8.1A to the target cells and the gpK8.1A blocking the radiolabeled HHV-8 binding shown here suggest that gpK8.1A plays an important role in the initial events of HHV-8 entry into susceptible cells. Our ongoing studies show that anti-gpK8.1A MAbs neutralize HHV-8 infectivity (data not shown). Inhibition of $\Delta \mathrm{TMgpK} 8.1 \mathrm{~A}$ binding 
by heparin, binding of $\Delta \mathrm{TMgpK} 8.1 \mathrm{~A}$ to the HS-expressing CHO-K1 cells, limited binding to the mutant derivatives of $\mathrm{CHO}$ cell lines lacking HS, specific binding of $\Delta \mathrm{TMgpK} 8.1 \mathrm{~A}$ to HS but not to other GAGs, and the binding of virion gpK8.1A with heparin clearly demonstrate that gpK8.1A is involved in the interaction with HS. Even though heparin lowered the level of $\Delta \mathrm{TMgpK} 8.1 \mathrm{~A}$ binding, the absence of complete inhibition suggests the interaction with other cell surface molecules. The low percentage of binding of $\Delta \mathrm{TMgpK} 8.1 \mathrm{~A}$ to the $\mathrm{CHO}$ mutant cells lacking HS also reinforces this suggestion. Our results indicate that $\Delta \mathrm{TMgpK} 8.1$ interaction with $\mathrm{HS}$ is the first important set of ligand-receptor interaction which may lead to the binding of one or more second receptor(s) essential for the subsequent viral entry process (23). The putative second receptor for gpK8.1A needs to be identified.

Inspection of the structure of heparin and/or HS and sequence analysis of the heparin-binding domain (HBD) of several proteins suggested that the negatively charged sulfate or carboxylate groups on heparin could interact via electrostatic interactions to positively charged cationic residues in a protein or peptide $(28,42,54)$. HBDs are enriched with positively charged basic amino acids (lysine, arginine, and histidine). Two typical heparin motifs (XBBXBX and XBBBXXBX) have been identified, where " $\mathrm{B}$ " is a basic residue and " $\mathrm{X}$ " can be any other residue but is usually a hydrophobic residue (8). Analysis of amino acid sequence of gpK8.1A revealed two possible, although atypical heparin-binding motifs: gpK8.1A-H1 $\left({ }^{150} \mathrm{SRTT}\right.$ RIRV $^{157}$, XBXXBXBX) and gpK8.1A-H2 ( ${ }^{182}$ TRGRDAHY $^{189}$, XBXBXXBX). Whether these gpK8.1A putative HBDs play a role in the interaction with $\mathrm{HS}$ requires further investigation. It is also possible that several other weak and/or high-affinity HBDs may appear in HHV-8 gpK8.1A in its native quaternary structure, since the basic amino acids separated apart may lie juxtaposed, forming a typical HBD.

Among the eight HHVs, HS has been shown to mediate the attachment of HSV-1, HSV-2, HCMV, HHV-7, and HHV-8 $(2,21,24,30,31,33,35,37,45-47,49,51,59)$. In alphaherpesviruses, the glycoproteins $\mathrm{gB}$ and $\mathrm{gC}$ are known to bind cell surface HS $(21,24,30,31,33,51)$. The $\mathrm{gC}$ homologue of alphaherpesviruses is absent in the beta- and gammaherpesviruses, and the gBs of HCMV (betaherpesvirus) and BHV-4 (gammaherpesvirus) have been shown to mediate the HS binding of these viruses $(35,45,57)$. Predictive analysis of HHV-8 sequence revealed the presence of putative HBD in HHV-8 gB. Ongoing studies show that HHV-8 envelope-associated gB also binds $\mathrm{HS}$ and the $75-$ and $54-\mathrm{kDa}$ proteins precipitated by heparin-agarose from the biotinylated virus (Fig. 8, lane 2) represent the two cleaved-disulfide linked forms of HHV-8 gB (S. M. Akula et al. unpublished results). The presence of two or more heparin-binding glycoproteins within a single virus is not unexpected, since all well-studied human alpha- and betaherpesviruses contain at least two HS binding glycoproteins, e.g., $\mathrm{gC}$ and $\mathrm{gB}$ for $\mathrm{HSV}-1$ and HSV-2, gB and $\mathrm{gCII}$ for HCMV, and gB and gp65 for HHV-7 (30, 31, 35, 37, 45, 49). The presence of two-HS binding proteins within the same virus indicates the importance of cell surface HS as receptors for viral attachment. HSV $-1 \mathrm{gC}$ and $\mathrm{gB}$ exhibit differences in their relative affinities for distinct cell surface $\mathrm{HS}$ proteoglycans (30). Whether HHV-8 gpK8.1A and gB also exhibit such differences needs to be studied.

\section{ACKNOWLEDGMENTS}

This study was supported in part by Public Health Service grant CA82056 to B.C

We thank E. Stephens for critically reading the manuscript and for the use of the Nikon Magna firewire digital imaging system. We thank Clark Bloomer at the Biotechnology Center, University of Kansas Medical Center, Kansas City, for sequencing the DNA.

\section{REFERENCES}

1. Albrecht, J. C., J. Nicholas, D. Biller, K. R. Cameron, B. Biesinger, C. Newman, S. Wittmann, M. A. Craxton, H. Coleman, B. Fleckenstein, and R. W. Honness. 1992. Primary structure of the herpesvirus saimiri genome. J. Virol. 66:5047-5058.

2. Akula, S. M., F.-Z. Wang, J. Vierira, and B. Chandran. 2001. Human herpesvirus 8 (HHV-8/KSHV) infection of target cells involves interaction with heparan sulfate. Virology 282:245-255.

3. Ballestas, M. E., P. A. Chatis, and K. M. Kaye. 1999. Efficient persistence of extrachromosomal KSHV DNA mediated by latency-associated nuclear antigen. Science 284:641-644.

4. Blasig, C., C. Zietz, B. Haar, F. Neipel, S. Esser, N. H. Brockmeyer, E. Tschachler, S. Colombini, B. Ensoli, and M. Sturzl. 1997. Monocytes in Kaposi's sarcoma lesions are productively infected by human herpesvirus 8 . J. Virol. 71:7963-7968.

5. Boshoff, C., T. F. Schulz, M. M. Kennedy, A. K. Graham, C. Fisher, A. Thomas, J. O. McGee, R. A. Weiss, and J. J. O'Leary. 1995. Kaposi's sarcoma-associated herpesvirus infects endothelial and spindle cells. Nat. Med. 1:1274-1278.

6. Boyle, K. A., and T. Compton. 1998. Receptor-binding properties of a soluble form of human cytomegalovirus glycoprotein B. J. Virol. 72:1826-1833.

7. Byrnes, A. P., and D. E. Griffin. 1998. Binding of Sindbis virus to cell surface heparan sulfate. J. Virol. 72:7349-7356.

8. Cardin, A. D., and H. J. Weintraub. 1989. Molecular modeling of proteinglycosaminoglycan interactions. Arteriosclerosis 9:21-32.

9. Cesarman, E., P. S. Moore, P. H. Rao, G. Inghirami, D. M. Knowles, and Y. Chang. 1995. In vitro establishment and characterization of two acquired immunodeficiency syndrome-related lymphoma cell lines (BC-1 and BC-2) containing Kaposi's sarcoma-associated herpesvirus-like (KSHV) DNA sequences. Blood 86:2708-2714.

10. Chandran, B., C. Bloomer, S. R. Chan, L. Zhu, E. Goldstein, and R. Horvat. 1998. Human herpesvirus-8 ORF K8.1 gene encodes immunogenic glycoproteins generated by spliced transcripts. Virology 249:140-149.

11. Chan, S. R., C. Bloomer, and B. Chandran. 1998. Identification and characterization of Human herpesvirus- 8 lytic cycle associated ORF 59 protein and the encoding cDNA by monoclonal antibody. Virology 240:118-128.

12. Chang, Y., E. Cesarman, M. S. Pessin, F. Lee, J. Culpepper, D. M. Knowles, and P. S. Moore. 1994. Identification of herpesvirus-like DNA sequences in AIDS-associated Kaposi's sarcoma. Science 266:1865-1869.

13. Chatlynne, L. G., W. Lapps, M. Handy, Y. Q. Huang, R. Masood, A. S. Hamilton, J. W. Said, H. P. Koeffler, M. H. Kaplan, A. Friedman-Kien, P. S. Gill, J. E. Whitman, and D. V. Ablashi. 1998. Detection and titration of human herpesvirus-8-specific antibodies in sera from blood donors, acquired immunodeficiency syndrome patients, and Kaposi's sarcoma patients using a whole virus enzyme-linked immunosorbent assay. Blood 92:53-58

14. Chung, C. S., J. C. Hsiao, Y. S. Chang, and W. Chang. 1998. A27L protein mediates vaccinia virus interaction with cell surface heparan sulfate. J. Virol. 72:1577-1585.

15. Decker, L. L., P. Shankar, G. Khan, R. B. Freeman, B. J. Dezube, J. Lieberman, and D. A. Thorley-Lawson. 1996. The Kaposi's sarcoma-associated herpesvirus (KSHV) is present as an intact latent genome in KS tissue but replicates in the peripheral blood mononuclear cells of KS patients. J. Exp. Med. 184:283-288.

16. Diamond, C., S. J. Brodie, J. N. Krieger, M. L. Huang, D. M. Koelle, K. Diem, D. Muthui, and L. Corey. 1998. Human herpesvirus 8 in the prostate glands of men with Kaposi's sarcoma. J. Virol. 72:6223-6227.

17. Dupin, N., C. Fisher, P. Kellam, S. Ariad, M. Tulliez, N. Franck, E. van Marck, D. Salmon, I. Gorin, J. P. Escande, R. A. Weiss, K. Alitalo, and C. Boshoff. 1999. Distribution of human herpesvirus-8 latently infected cells in Kaposi's sarcoma, multicentric Castleman's disease, and primary effusion lymphoma. Proc. Natl. Acad. Sci. USA 96:4546-4551.

18. Esko, J. D., T. E. Stewart, and W. H. Taylor. 1985. Animal cell mutants defective in glycosaminoglycan biosynthesis. Proc. Natl. Acad. Sci. USA 82:3197-3201.

19. Feldman, S. A., S. Audet, and J. A. Beeler. 2000. The fusion glycoprotein of human respiratory syncytial virus facilitates virus attachment and infectivity via an interaction with cellular heparan sulfate. J. Virol. 74:6442-6447.

20. Flore, O., S. Rafii, S. Ely, J. J. O'Leary, E. M. Hyjek, and E. Cesarman. 1998. Transformation of primary human endothelial cells by Kaposi's sarcomaassociated herpesvirus. Nature 394:588-592.

21. Flynn, S. J., and P. Ryan. 1996. The receptor-binding domain of pseudorabies virus glycoprotein $\mathrm{gC}$ is composed of multiple discrete units that are 
functionally redundant. J. Virol. 70:1355-1364.

22. Gong, M., and E. Kieff. 1990. Intracellular trafficking of two major EpsteinBarr virus glycoproteins, gp350/220 and gp110. J. Virol. 64:1507-1516.

23. Haywood, A. M. 1994. Virus receptors: binding, adhesion strengthening, and changes in viral structure. J. Virol. 68:1-5.

24. Herold, B. C., R. J. Visalli, N. Susmarski, C. R. Brandt, and P. G. Spear. 1994. Glycoprotein C-independent binding of herpes simplex virus to cells requires cell surface heparan sulphate and glycoprotein B. J. Gen. Virol. 75:1211-1222.

25. Hutt-Fletcher, L. M., N. Balachandran, and P. A. LeBlane. 1986. Modification of Epstein-Barr virus replication by tunicamycin. J. Virol. 57:117-123.

26. Jackson, T., F. M. Ellard, R. A. Ghazaleh, S. M. Brookes, W. E. Blakemore, A. H. Corteyn, D. I. Stuart, J. W. Newman, and A. M. King. 1996. Efficient infection of cells in culture by type $\mathrm{O}$ foot-and-mouth disease virus requires binding to cell surface heparan sulfate. J. Virol. 70:5282-5287.

27. Kedes, D. H., E. Operskalski, M. Busch, R. Kohn, J. Flood, and D. Ganem. 1996. The seroepidemiology of human herpesvirus 8 (Kaposi's sarcomaassociated herpesvirus): distribution of infection in KS risk groups and evidence for sexual transmission. Nat. Med. 2:918-924.

28. Kjellen, L., and U. Lindahl. 1991. Proteoglycans: structures and interactions. Annu. Rev. Biochem. 60:443-475.

29. Krusat, T., and H. J. Streckert. 1997. Heparin-dependent attachment of respiratory syncytial virus (RSV) to host cells. Arch. Virol. 142:1247-1254.

30. Laquerre, S., R. Argnani, D. B. Anderson, S. Zucchini, R. Manservigi, and J. C. Glorioso. 1998. Heparan sulfate proteoglycan binding by herpes simplex virus type 1 glycoproteins $\mathrm{B}$ and $\mathrm{C}$, which differ in their contributions to virus attachment, penetration, and cell-to-cell spread. J. Virol. 72:6119-6130.

31. Liang, X., L. A. Babiuk, and T. J. Zamb. 1993. Mapping of heparin-binding structures on bovine herpesvirus 1 and pseudorabies virus gIII glycoproteins. Virology 194:233-243.

32. Lidholt, K., J. L. Weinke, C. S. Kiser, F. N. Lugemwa, K. J. Bame, S. Cheifetz, J. Massague, U. Lindahl, and J. D. Esko. 1992. A single mutation affects both $\mathrm{N}$-acetylglucosaminyltransferase and glucuronosyltransferase activities in a Chinese hamster ovary cell mutant defective in heparan sulfate biosynthesis. Proc. Natl. Acad. Sci. USA 89:2267-2271.

33. Mettenleiter, T. C., L. Zsak, F. Zuckermann, N. Sugg, H. Kern, and T. Ben-Porat. 1990. Interaction of glycoprotein gIII with a cellular heparinlike substance mediates adsorption of pseudorabies virus. J. Virol. 64:278-286.

34. Moses, A. V., K. N. Fish, R. Ruhl, P. P. Smith, J. G. Strussenberg, L. Zhu, B. Chandran, and J. A. Nelson. 1999. Long-term infection and transformation of dermal microvascular endothelial cells by human herpesvirus 8 . J. Virol. 73:6892-6902.

35. Navarro, D., P. Paz, S. Tugizov, K. Topp, J. La Vail, and L. Pereira. 1993. Glycoprotein B of human cytomegalovirus promotes virion penetration into cells, transmission of infection from cell to cell, and fusion of infected cells. Virology 197:143-158.

36. Neipel, F., J. C. Albrecht, and B. Fleckenstein. 1997. Cell-homologous genes in the Kaposi's sarcoma-associated rhadinovirus human herpesvirus 8: determinants of its pathogenicity? J. Virol. 71:4187-4192.

37. Neyts, J., R. Snoeck, D. Schols, J. Balzarini, J. D. Esko, A. Van Schepdael, and E. De Clercq. 1992. Sulfated polymers inhibit the interaction of human cytomegalovirus with cell surface heparan sulfate. Virology 189:48-58.

38. Patel, M., M. Yanagishita, G. Roderiquez, D. C. Bou-Habib, T. Oravecz, V. C. Hascall, and M. A. Norcross. 1993. Cell-surface heparan sulfate proteoglycan mediates HIV-1 infection of T-cell lines. AIDS Res. Hum. Retrovir. 9:167-174.

39. Renne, R., D. Blackbourn, D. Whitby, J. Levy, and D. Ganem. 1998. Limited transmission of Kaposi's sarcoma-associated herpesvirus in cultured cells. J. Virol. 72:5182-5188.

40. Renne, R., W. Zhong, B. Herndier, M. McGrath, N. Abbey, D. Kedes, and D. Ganem. 1996. Lytic growth of Kaposi's sarcoma-associated herpesvirus (human herpesvirus 8) in culture. Nat. Med. 2:342-346.

41. Roderiquez, G., T. Oravecz, M. Yanagishita, D. C. Bou-Habib, H. Mostowski, and M. A. Norcross. 1995. Mediation of human immunodeficiency virus type 1 binding by interaction of cell surface heparan sulfate proteoglycans with the V3 region of envelope gp120-gp41. J. Virol. 69:22332239.

42. Rostand, K. S., and J. D. Esko. 1997. Microbial adherence to and invasion through proteoglycans. Infect. Immun. 65:1-8.
43. Russo, J. J., R. A. Bohenzky, M. C. Chien, J. Chen, M. Yan, D. Maddalena, J. P. Parry, D. Peruzzi, I. S. Edelman, Y. Chang, and P. S. Moore. 1996. Nucleotide sequence of the Kaposi sarcoma-associated herpesvirus (HHV8). Proc. Natl. Acad. Sci. USA 93:14862-14867.

44. Schulz, T. F., Y. Chang, and P. S. Moor. 1998. Kaposi's sarcoma-associated herpesvirus (human herpesvirus 8), p. 87-134. In D. J. McCance (ed.), Human tumor viruses. American Society for Microbiology, Washington, D.C.

45. Secchiero, P., D. Sun, A. L. De Vico, R. W. Crowley, M. S. Reitz, Jr., G. Zauli, P. Lusso, and R. C. Gallo. 1997. Role of the extracellular domain of human herpesvirus 7 glycoprotein B in virus binding to cell surface heparan sulfate proteoglycans. J. Virol. 71:4571-4580.

46. Shieh, M. T., and P. G. Spear. 1994. Herpesvirus-induced cell fusion that is dependent on cell surface heparan sulfate or soluble heparin. J. Virol. 68: 1224-1228.

47. Shukla, D., J. Liu, P. Blaiklock, N. W. Shworak, X. Bai, J. D. Esko, G. H. Cohen, R. J. Eisenberg, R. D. Rosenberg, and P. G. Spear. 1999. A novel role for 3-O-sulfated heparan sulfate in herpes simplex virus 1 entry. Cell 99:1322.

48. Sisk, W. P., J. D. Bradley, R. J. Leipold, A. M. Stoltzfus, M. Ponce de Leon, M. Hilf, C. Peng, G. H. Cohen, and R. J. Eisenberg. 1994. High-level expression and purification of secreted forms of herpes simplex virus type 1 glycoprotein gD synthesized by baculovirus-infected insect cells. J. Virol. 68:766-775.

49. Skrincosky, D., P. Hocknell, L. Whetter, P. Secchiero, B. Chandran, and S. Dewhurst. 2000. Identification and analysis of a novel heparin-binding glycoprotein encoded by human herpesvirus 7. J. Virol. 74:4530-4540.

50. Smith, M. S., C. Bloomer, R. Horvat, E. Goldstein, J. M. Casparian, and B. Chandran. 1997. Detection of human herpesvirus 8 DNA in Kaposi's sarcoma lesions and peripheral blood of human immunodeficiency virus-positive patients and correlation with serologic measurements. J. Infect. Dis. 176:84-93.

51. Spear, P. G. 1993. Entry of alphaherpesviruses into cells. Semin. Virol. 4:167-180.

52. Staskus, K. A., W. Zhong, K. Gebhard, B. Herndier, H. Wang, R. Renne, J. Beneke, D. Pudney, J. Anderson, D. Ganem, and A. T. Haase. 1997. Kaposi's sarcoma-associated herpesvirus gene expression in endothelial (spindle) tumor cells. J. Virol. 71:715-719.

53. Stewart, J. P., N. J. Janjua, S. D. Pepper, G. Bennion, M. Mackett, T. Allen, A. A. Nash, and J. R. Arrand. 1996. Identification and characterization of murine gammaherpesvirus 68 gp150: a virion membrane glycoprotein. J. Virol. 70:3528-3535.

54. Stringer, S. E., and J. T. Gallagher. 1997. Heparan sulphate. Int. J. Biochem. Cell Biol. 29:709-714.

55. Summerford, C., and R. J. Samulski. 1998. Membrane-associated heparan sulfate proteoglycan is a receptor for adeno-associated virus type 2 virions. J. Virol. 72:1438-1445.

56. Thorley-Lawson, D. A., and K. Geilinger. 1980. Monoclonal antibodies against the major glycoprotein (gp350/220) of Epstein-Barr virus neutralize infectivity. Proc. Natl. Acad. Sci. USA 77:5307-5311.

57. Vanderplasschen, A., M. Bublot, J. Dubuisson, P. P. Pastoret, and E. Thiry. 1993. Attachment of the gammaherpesvirus bovine herpesvirus 4 is mediated by the interaction of gp 8 glycoprotein with heparinlike moieties on the cell surface. Virology 196:232-240.

58. Vieira, J., P. O'Hearn, L. Kimball, B. Chandran, and L. Corey. 2001. Activation of Kaposi's sarcoma-associated herpesvirus (HHV8) lytic replication by human cytomegalovirus. J. Virol. 75:1378-1386.

59. WuDunn, D., and P. G. Spear. 1989. Initial interaction of herpes simplex virus with cells is binding to heparan sulfate. J. Virol. 63:52-58.

60. Zhu, L., V. Puri, and B. Chandran. 1999. Characterization of human herpesvirus-8 8-K8.1A/B glycoproteins by monoclonal antibodies. Virology 262: 237-249.

61. Zhu, L., R. Wang, A. Sweat, E. Goldstein, R. Horvat, and B. Chandran. 1999. Comparison of human sera reactivities in immunoblots with recombinant human herpesvirus (HHV)-8 proteins associated with the latent (ORF73) and lytic (ORFs $65, \mathrm{~K} 8.1 \mathrm{~A}$, and $\mathrm{K} 8.1 \mathrm{~B}$ ) replicative cycles and in immunofluorescence assays with HHV-8 infected BCBL-1 cells. Virology 256:381392. 